\title{
THE PACE OF ECOSYSTEM DEVELOPMENT OF CONSTRUCTED SPARTINA ALTERNIFLORA MARSHES
}

\author{
Christopher Craft, ${ }^{1.7}$ Patrick Megonigal,, 2.3 Stephen Broome, ${ }^{4}$ Jan Stevenson,,${ }^{5}$ Robert Freese, ${ }^{4}$ \\ JefF CORNell, ${ }^{3}$ LeI ZHENG, ${ }^{5}$ AND John SACCO ${ }^{6}$ \\ 'School of Public and Environmental Affairs, Indiana University, Bloomington, Indiana 47405 USA \\ ${ }^{2}$ Smithsonian Environmental Research Laboratory, P.O. Box 28, Edgewater, Maryland 21037 USA \\ ${ }^{3}$ Department of Biology, George Mason University, Fairfax, Virginia 22030 USA \\ ${ }^{4}$ Department of Soil Science, North Carolina State University. Raleigh, North Carolina 27695 USA \\ sDepartment of Zoology, Michigan State University, East Lansing, Michigan 48824 USA \\ 'Office of Natural Resources Restoration, New Jersey Department of Environmental Protection, \\ Trenton, New Jersey 08625 USA
}

\begin{abstract}
Ecological attributes were measured along a chronosequence of 1 - to 28 -yrold, constructed Spartina alterniflora marshes to identify trajectories and rates of ecosystem development of wetland structure and function. Attributes related to biological productivity and diversity (Spartina, epiphytic and sediment algae, benthic invertebrates), soil development (sediment deposition, organic $\mathrm{C}, \mathrm{N}, \mathrm{P}$, organic matter quality), and microbial processes ( $\mathrm{C}$ mineralization) were compared among eight constructed marshes and eight paired natural reference marshes. Most ecological attributes developed in a predictable manner over time, and most achieved equivalence to natural marshes 5-15 yr after marsh construction. An exception was soil organic $C$ and $N$ pools $(0-30 \mathrm{~cm})$ that, after $28 \mathrm{yr}$, were significantly lower in constructed marshes. Development of habitat structure (Spartina stem height and density) and biodiversity (algae and invertebrates) developed concurrently with functional characteristics such as biomass, chlorophyll $a$, and invertebrate density. Processes related to hydrology, sediment deposition and soil $\mathrm{C}$ and $\mathrm{N}$ accumulation, developed almost instantaneously with the establishment of Spartina, and young (1- to 3-yr-old), constructed marshes trapped sediment and sequestered $\mathrm{N}$ at higher rates than comparable reference marshes. Development of heterotrophic activity (C mineralization, invertebrate density) was strongly linked to surface $(0-10 \mathrm{~cm})$ soil organic $C$ content. Ecosystem development of constructed (and natural) salt marshes depended on a minimum of $100 \mathrm{~g} \mathrm{~N} / \mathrm{m}^{2}(0.05-$ $0.1 \% \mathrm{~N})$ to support emergent vegetation and $1000 \mathrm{~g} \mathrm{C} / \mathrm{m}^{2}(0.5-1 \% \mathrm{C})$ to sustain the heterotrophic community.
\end{abstract}

Key words: chronosequence; ecosystem development; North Carolina; reference wetland; restoration and rehabilitation; salt marshes; Spartina alterniffora; wetland creation.

\section{INTRODUCTION}

Wetlands frequently are constructed to mitigate for the loss of ecosystem services caused when human activities, such as surface mining, oil and natural gas extraction, highway and pipeline construction, and urban-suburban development, lead to the destruction or degradation of natural wetlands (Kusler and Kentula 1989, National Research Council 1992, Thayer 1992, Zedler 1996b, 2001, Zedler et al. 2001). Wetland construction typically involves recreating wetland hydrology and establishing hydrophytic vegetation by planting, seeding, or adding donor wetland soil or seed bank (Kusler and Kentula 1989). However, many wetland construction projects fail to monitor the development of wetland dependent ecosystem services following construction (National Research Council 1992). When post-construction monitoring is undertaken, it usually is limited to the first few years following creation/res-

Manuscript received II March 2002; revised 10 October 2002; accepted 14 January 2003. Corresponding Editor: I. C. Burke.

${ }^{7}$ E-mail: ccraft@indiana.edu toration, and only a few ecological attributes related to vegetation (e.g., percent cover, biomass) are monitored (Zedler 2000).

Post-construction evaluation of created and restored wetlands is limited by the paucity of long-term data sets that describe the development of wetland-dependent ecosystem services (Streever 2000). One study has monitored a suite of ecosystem services, but the monitoring period $(3 \mathrm{yr})$ was too short to assess whether the constructed wetland provided the same level of functionality as natural wetlands (Mitsch et al. 1998). Other studies have tracked the development of wetlanddependent ecological attributes for a longer time (5$25 \mathrm{yr}$ ), but the suite of ecosystem services measured was limited in number (Zedler 1996b,2000, 2001, Craft et al. 1999, 2002).

Long-term post-construction monitoring of constructed wetlands suggest that there is an initial lag before these ecosystems provide the same level of ecosystem services as natural wetlands that they were designed to replace (Craft et al. 1988, Sacco et al. 1994, Levin et al. 1996, Scatolini and Zedler 1996, Zedler 
a.

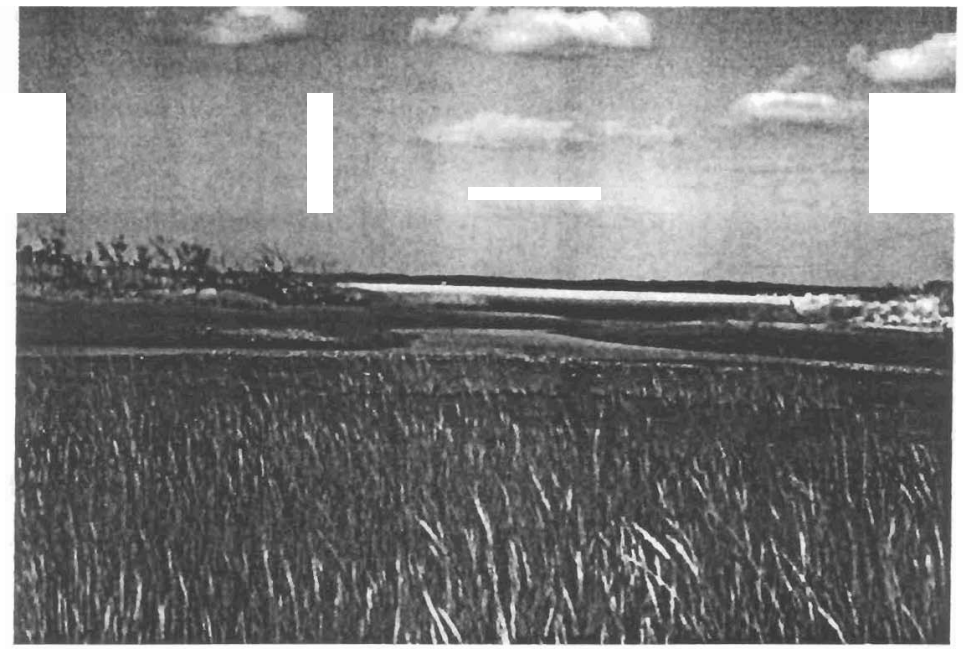

b.

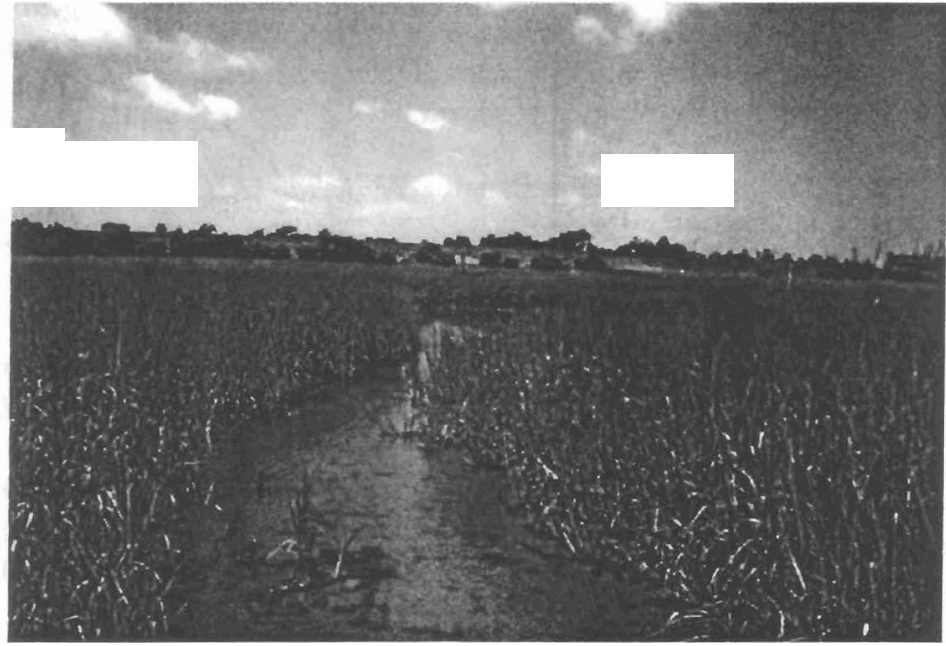

C.

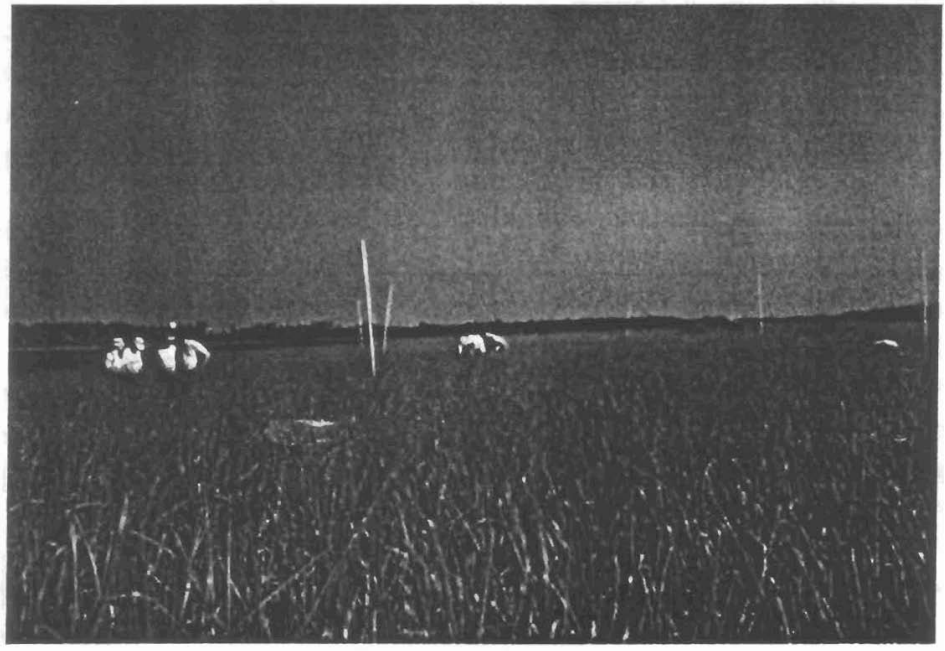

Fig. 1. Photographs of the (a) 3-yr-old (Consultant Marsh), (b) 8-yr-old (Port Marsh), and (c) 28-yr-old (Snow's Cut) constructed marshes. The photographs were taken in June (Consultant Marsh, Port Marsh) and October (Snow's Cut) 1998. Photographs by Christopher Craft. 
TABLE 1. Characteristics of constructed and natural reference Spartina alterniflora salt marsh study sites

\begin{tabular}{|c|c|c|c|c|c|c|}
\hline Marsh & $\begin{array}{l}\text { Size } \\
\text { (ha) } \dagger\end{array}$ & $\begin{array}{l}\text { Age } \\
(y r) \ddagger\end{array}$ & $\begin{array}{c}\text { Tidal } \\
\text { range }(m) \dagger\end{array}$ & $\begin{array}{l}\text { Salinity } \\
(p p t)^{\dagger}\end{array}$ & $\begin{array}{c}\text { Geomorphic } \\
\text { positiont }\end{array}$ & $\begin{array}{c}\text { Soil } \\
\text { classification } \$\end{array}$ \\
\hline 1) $\mathrm{DOT}$ & 0.9 & 1 & 1.0 & $20-30$ & back barrier flats & typic psammaquent \\
\hline 2) Consultant & 1.0 & 3 & 1.0 & $17-32$ & back barrier flats & typic hydraquent \\
\hline 3) Port & 1.0 & 8 & 1.0 & $18-30$ & back barrier flats & typic psammaquent \\
\hline 4) Swansboro & 1.2 & 11 & I.1 & $20-30$ & riverine & typic psammaquent \\
\hline 5) Dill's Creek & 0.3 & 13 & 1.0 & $14-33$ & submerged upland & typic hydraquent \\
\hline 6) Pine Knoll & 0.3 & 24 & 1.0 & $20-30$ & back barrier fringe & typic psammaquent \\
\hline 7) Marine lab & 0.2 & 26 & 1.0 & $20-30$ & back barrier flats & typic hydraquent \\
\hline 8) Snow's Cut & 0.8 & 28 & 1.2 & $5-20$ & riverine & typic medisaprist \\
\hline
\end{tabular}

Note: Marshes were constructed for shoreline stabilization (marsh number 6), dredge spoil stabilization $(7,8)$, research $(3,4)$, mitigation on dredge spoil $(1,2)$, and mitigation on graded upland soil (5).

$\dagger$ Constructed and natural reference marshes. Salinity, in ppt, is grams of salt per kilogram of water

Constructed marshes only.

$\$$ Natural reference marshes only. All constructed marsh soils are classified as typic psammaquents except Dill's Creek, which was classified as a typic hydraquent (USDA 1975)

2000). In some instances, certain ecosystem services that were lost when natural wetlands are degraded or destroyed required considerable time to develop (Craft et al. 1999, 2002) or never were adequately replaced (Zedler 1993). If wetland creation and restoration is to be successful at replacing wetland loss, it is important to know ( $\mathrm{l}$ ) how much time is needed for these ecosystems to achieve equivalence to natural wetlands and, (2) once equivalence is achieved, whether these ecosystems persist and provide long-term ecological benefits.

\section{Methods}

\section{Site description}

We used the chronosequence approach to assess ecosystem development of constructed Spartina alterniflora Loisel salt marshes. The chronosquence approach relies on selecting sites that have similar environmental conditions, but differ only with respect to their age. The obvious strength of this approach is that it "compresses" time, avoiding the need for long-term repeated measurements on a single site. A limitation of the approach is that, because of variable disturbance histories, differences among sites may be incorrectly attributed to ecosystem development rather than past disturbance events (Pickett 1989).

In this study, we measured a variety of ecological attributes in eight constructed marshes that possess similar tidal inundation, salinity, vegetation, and soils, but differed with respect to age (Table 1). Between 1970 and 1997, salt marsh wetlands were constructed along the North Carolina coast for a variety of purposes, including dredge spoil and shoreline stabilization, and mitigation of wetland loss (Figs. 1 and 2). Marshes were constructed by mechanically grading the planting substrate to intertidal elevation, then planting elevations between mean sea level and mean high water with cordgrass, Spartina alterniflora Loisel (Broome et al. 1988). Because the marshes are relatively young $(<30 \mathrm{yr})$, we are aware of construction practices and the disturbance history of the eight sites.
Although the constructed marshes were similar in most respects, they differed in their geomorphic or landscape position. Most marshes were located on extensive flats behind barrier islands (back barrier flats). Two marshes were located along intertidal rivers (riverine). The remaining two marshes consisted of a narrow fringe marsh and a submerged upland marsh (Table 1). Differences in geomorphic position might lead to differences in the rate of ecosystem development among the constructed marshes. To reduce this variability, each constructed marsh was paired with a nearby natural marsh of the same geomorphic position, salinity, and vegetation ( $S$. alterniflora) to serve as a reference against which to measure ecosystem development of individual constructed marshes. Reference wetlands were used to set performance goals for created and restored wetlands (Aronson et al. 1993a, b, 1995 , Brinson and Rheinhardt 1996, Rheinhardt et al. 1999, Whigham 1999). There was some concern, however, that using one or two references site does not capture the dynamic spatial variability among ecosystems of the same type (Pickett and Parker 1994). But, by pairing each constructed marsh with a reference marsh, we captured much of the dynamic spatial variability of the natural marshes that using one or two reference marshes does not capture.

Paired reference marshes were located adjacent to each corresponding constructed marsh so that marsh pairs had similar geomorphic position, tidal inundation, salinity, and vegetation, but often had different soil types (Table 1). In each natural marsh, the area sampled was comparable in size to the size of the constructed marsh (Table 1). Ecological attributes of reference marshes were statistically tested to determine whether references marshes could be "pooled" to create a single reference mean (see Statistical analysis). For all attributes, statistically significant differences among natural marshes precluded pooling sites so individual constructed marshes were compared with their respective reference marsh pair. 


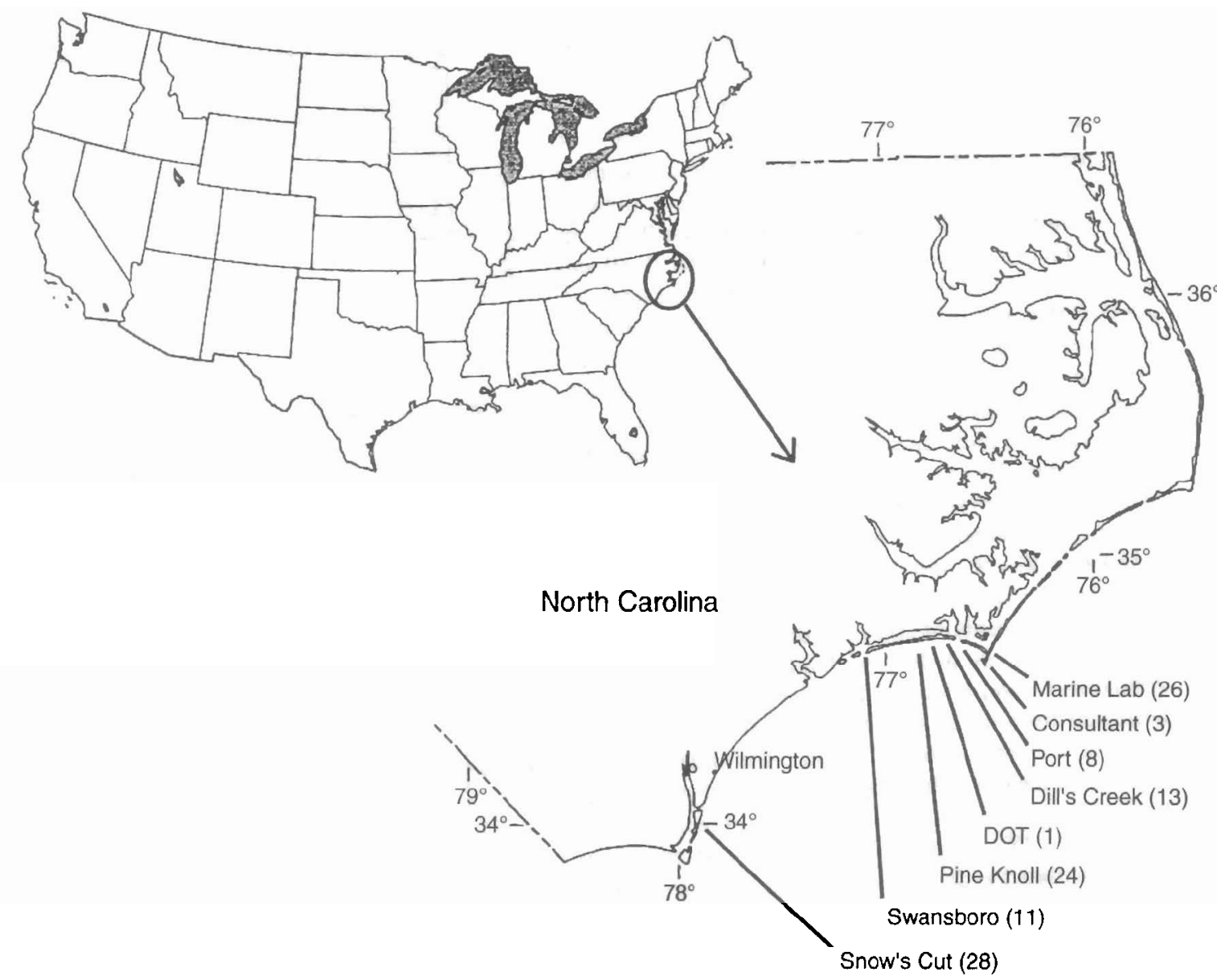

FIG. 2. Map showing the location of constructed Spartina alterniflora marshes along the North Carolina coast. Ages of constructed marshes in years are in parentheses.

\section{Sample collection and analysis}

We measured ecological attributes related to producers, consumers, and soil/microbial processes. Most attributes described community structure (Zedler and Lindig-Cisneros 2000), but indices of ecosystem function (e.g., biomass) also were measured. Direct measures of ecosystem function included sedimentation, soil organic $\mathrm{C}, \mathrm{N}$ and $\mathbf{P}$ accumulation, and soil organic carbon mineralization. Within each marsh, sampling was stratified with half of the samples randomly collected along the streamside (levee) zone and the other half randomly collected from the marsh interior (marsh plain). Because of the small number of vegetation samples $(n=5)$ collected from each zone, streamside and interior marsh samples were combined for statistical analyses.

Primary production was estimated by measurements of Spartina biomass and algae chlorophyll $a$. Aboveground biomass and macro-organic matter (MOM) of Spartina $(n=10$ vegetation and MOM samples per marsh) were collected in October 1998 and processed as described in Craft et al. (1999). Stem density and height of the five tallest stems were also measured.
Epiphytic and sediment algae samples $(n=8$ and 16 per marsh, respectively) were collected in 1998 and analyzed as described by L. Zheng, R. J. Stevenson, and C. B. Craft (unpublished manuscript). Secondary production was estimated by measuring the density of benthic invertebrates. Invertebrate samples $(n=25$ per marsh, $0-5 \mathrm{~cm}$ depth) were sampled, processed, and identified as described in Craft et al. (1999).

Soil processes consisted of measurements of sediment deposition and accumulation and storage of soil organic $C, N$, and $P$. Sediment deposition was measured two ways: (1) feldspar marker layers and (2) fine particles (silt plus clay) in surface soil. Feldspar was added to two $0.25-\mathrm{m}^{2}$ plots in each marsh in October 1998. Five months later (March 1999), five coies per plot were collected, and sediment deposition was measured as described by Cahoon (1994). Ten soil cores $(8.5 \mathrm{~cm}$ diameter by $30 \mathrm{~cm}$ deep) per marsh were collected in June 1998 for particle size analysis. Silt plus clay was measured in surface $0-10 \mathrm{~cm}$ subsamples using the hydrometer method (Gee and Bauder 1986). The same soil cores $(0-10 \mathrm{~cm}, 10-30 \mathrm{~cm})$ were analyzed for bulk density, organic $\mathrm{C}$, and total $\mathrm{N}$ and $\mathrm{P}$ as described in 
Craft et al. (1999) to quantify organic C and nutrient pools. In constructed marshes, accumulation of soil organic $\mathrm{C}, \mathrm{N}$, and $\mathrm{P}$ was calculated as $[(0-30 \mathrm{~cm}$ organic $\mathrm{C}, \mathrm{N}, \mathrm{P}$ pool $)-(10-30 \mathrm{~cm}$ organic $\mathrm{C}, \mathrm{N}, \mathrm{P}$ pool $) \times$ 1.5))/marsh age] (Craft et al. 1988). Accumulation rates were based on the assumption that, at time 0 , organic $C$ was uniformly distributed throughout the $0-30 \mathrm{~cm}$ depth. Thus, organic $\mathrm{C}$ enrichment of the $0-10 \mathrm{~cm}$ depth (relative to the $10-30 \mathrm{~cm}$ depth) represents organic $\mathrm{C}$ that accumulated since time 0 . All of our constructed marshes were mechanically graded such that the planting substrate consisted of the "C" horizon containing essentially no soil organic matter. Thus, our assumption of uniform soil organic $\mathrm{C}$ (and $\mathrm{N}$ ) content in the upper $30 \mathrm{~cm}$ of constructed marshes is valid, because we are evaluating ecosystem development during primary, rather than secondary succession.

Organic $\mathrm{C}, \mathrm{N}$, and $\mathrm{P}$ accumulation in reference marshes was determined using ${ }^{137} \mathrm{Cs}$ and ${ }^{210} \mathrm{~Pb}$ along with measurements of soil bulk density and organic $\mathrm{C}$ concentrations at $0-10 \mathrm{~cm}$ depth (Craft and Casey 2000 ). One core, $8.5 \mathrm{~cm}$ diameter by $30 \mathrm{~cm}$ deep, was collected from each natural marsh and sectioned into 2 -cm depth increments. ${ }^{137} \mathrm{Cs}$ and ${ }^{210} \mathrm{~Pb}$ of depth increments was measured by gamma analysis of the 661.62$\mathrm{keV}$ (kiloelectronvolt) and $46.5 \mathrm{-keV}$ photopeaks, respectively. ${ }^{137} \mathrm{Cs}-$ and ${ }^{210} \mathrm{~Pb}$-based vertical accretions were calculated as described in Craft and Casey (2000). Only soil cores containing interpretable ${ }^{137} \mathrm{Cs}$ and ${ }^{210} \mathrm{~Pb}$ profiles, such as the ones in Fig. 3, were used to calculate $\mathrm{C}, \mathrm{N}$, and $\mathrm{P}$ accumulation.

Quality of accumulating MOM ( $n=10$ per marsh) was determined gravimetrically by sequential extraction in $0.5 \mathrm{~mol} / \mathrm{L} \mathrm{H}_{2} \mathrm{SO}_{4}$ and cetyltrimethylammonium bromide to remove water-soluble extractives, followed by extraction with concentrated $\mathrm{H}_{2} \mathrm{SO}_{4}$ to remove cellulose (Ryan et al. 1990). The material remaining after extraction was combusted at $450^{\circ} \mathrm{C}$ for $8 \mathrm{~h}$. Lignin was calculated based on the mass lost during combustion (Ryan et al. 1990).

Microbial processes consisted of measurements of potential soil organic $\mathrm{C}$ mineralization. Carbon mineralization was measured by laboratory incubations under anaerobic conditions. Eight samples $(0-10 \mathrm{~cm})$ per marsh, $\sim 40 \mathrm{~g}$ wet mass, were collected in July 1999. Soils were sieved to remove roots, placed in $473-\mathrm{mL}$ capacity glass canning jars and flooded with saline water (30 ppt [grams of salt per kilogram of water]), leaving a $250-\mathrm{mL}$ headspace. The jars were sealed and incubated at $25^{\circ} \mathrm{C}$ under $\mathrm{N}_{2}$ atmosphere. $\mathrm{CO}_{2}$ fluxes were measured roughly every $2 \mathrm{wk}$ over $76 \mathrm{~d}$ beginning on day 14. On each date, three 1-min measurements of $\mathrm{CO}_{2}$ efflux measurements were made per jar by replacing the lid with a modified LI-COR 6400 infrared gas analyzer (LI-COR, Lincoln, Nebraska, USA). The efflux rate was calculated by regression of the $\mathrm{CO}_{2}$ concentration vs. time, and the average rate of $\mathrm{CO}_{2}$ evolution was calculated for each marsh for the 76-d
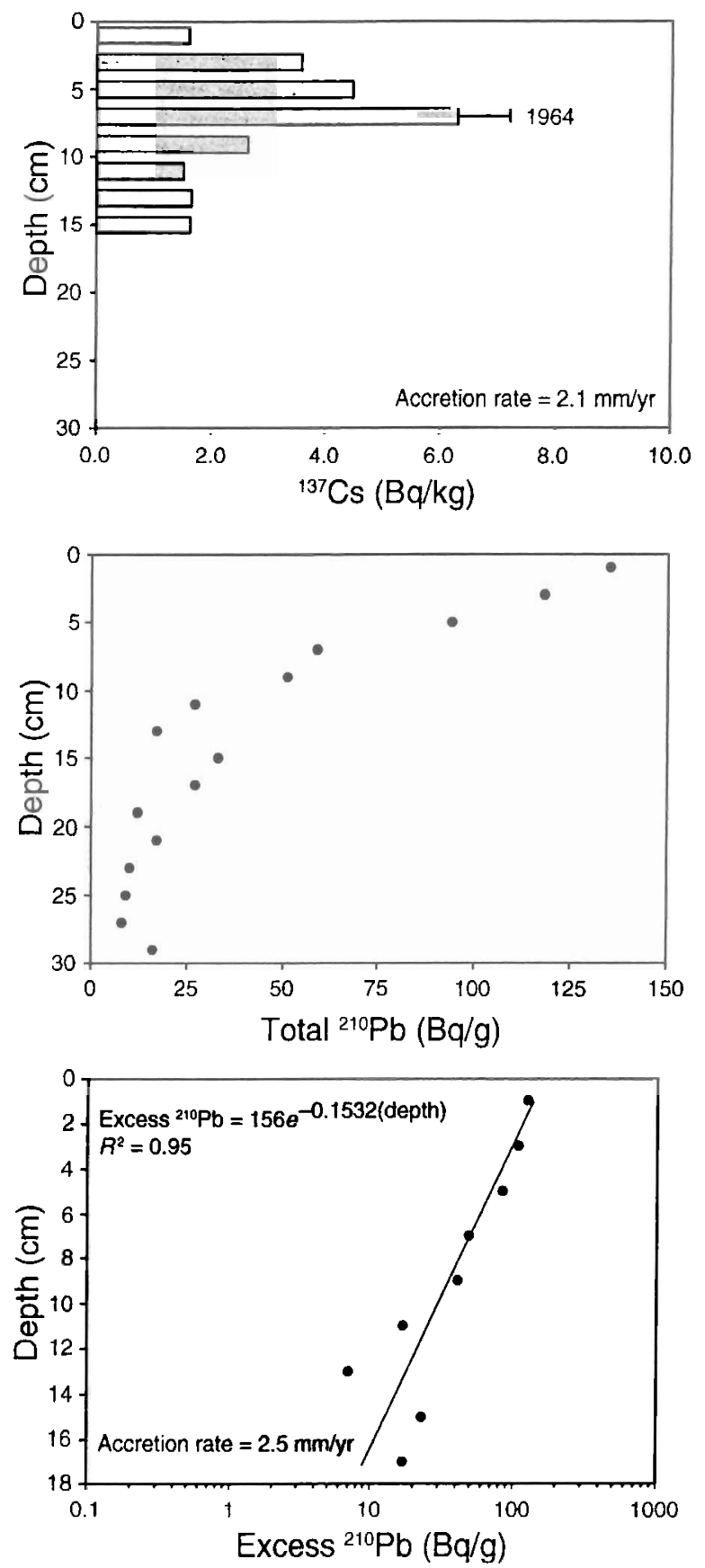

FIG. 3. Depth distribution of ${ }^{137} \mathrm{Cs}$, total ${ }^{210} \mathrm{~Pb}$, and excess ${ }^{210} \mathrm{~Pb}$ in a soil core collected from the natural DOT Marsh. Only profiles like these, that are interpretable, were used to calculate soil organic $\mathrm{C}, \mathrm{N}$, and $\mathrm{P}$ accumulation of natural marshes. The error bar for 1464 in the top panel is the counting error of the gamma spectrometer.

period. Periodically, $50 \mathrm{~mL}$ of soil water was removed and replaced with fresh saline water (30 ppt) to maintain salinity and reduce the concentration-of potential toxic substances.

Measurements of aerobic $\mathrm{C}$ mineralization were not made even though it is likely that, in young constructed 

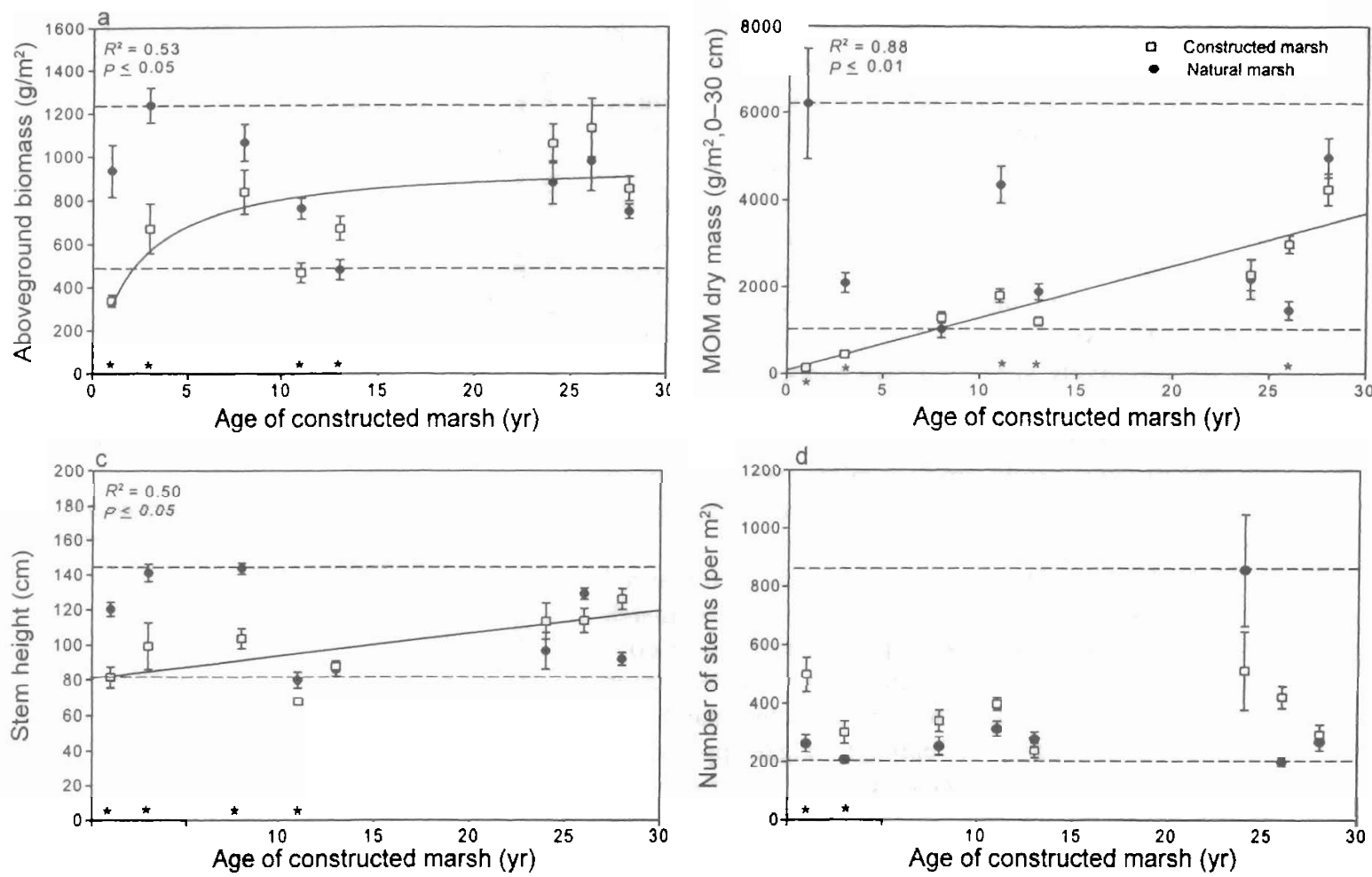

FIG. 4. (a) Aboveground biomass, (b) macro-organic matter, (c) stem height, and (d) stem density of Spartina alterniflora along a chronosequence of constructed salt marshes and natural reference marshes. Asterisks $\left({ }^{*}\right)$ indicate that the constructed and paired reference marshes are significantly different $(P \leq 0.05)$ according to Student's $t$ test. Dashed lines represent the range of values measured in the natural marshes.

marshes, aerobic decomposition may be more important than anaerobic decomposition as a result of coarser (sandy) soil texture and higher redox potential (Eh). As constructed marshes age, accumulation of fine sediments and organic matter may lead to decreased soil Eh with anaerobic processes becoming more important to decomposition and $\mathrm{C}$ mineralization.

\section{Statistical analysis}

Analysis of variance (ANOVA) was used to test for differences in ecological attributes among natural marshes to determine whether natural marshes could be pooled to calculate a single overall reference mean. ANOVA followed by the Ryan-Einot-Gabriel-Welsch multiple range test (SAS 1996) revealed significant differences $(P \leq 0.05)$ among natural marshes that were sometimes, but not always, related to differences in geomorphic position. For this reason, pairwise $t$ tests were used to test for differences in ecological attributes between constructed and natural marsh pairs (SAS 1996). Where appropriate, tests were based on the assumption of unequal variances. All tests of significance were made at $P=0.05$. Regression analysis was used to describe relationships between the measured attributes and constructed marsh age.

\section{Constructed Marsh Ecosystem Development}

\section{Structure and function of producers and consumers}

Primary producers.-Aboveground biomass of Spartina was significantly related to constructed marsh age $\left(R^{2}=0.53\right)$, but considerable time elapsed before end-of-season aboveground biomass developed to levels found in natural marshes (Fig. 4a). The 1-, 3-, and 1l-yr-old constructed marshes contained significantly less aboveground biomass than comparable natural marshes. Aboveground biomass in the 13-yr-old constructed marsh, however, was significantly greater than the reference marsh. The relationship between aboveground biomass vs. marsh age improved dramatically when the 11 -yr-old marsh was excluded from the analysis $\left(R^{2}=0.87\right)$.

Macro-organic matter (MOM), the living and dead root and rhizome mat, also increased with constructed marsh age $\left(R^{2}=0.88\right)$, but it required longer to develop than aboveground biomass. Although MOM in the 8yr-old constructed marsh and paired reference marsh were similar, MOM did not consistently achieve equivalence to the natural marshes for 15 yr (Fig. 4b).

Like biomass, Spartina stem height increased with constructed marsh age $\left(R^{2}=0.50\right.$, and $R^{2}=0.70$ excluding the 11 -yr-old marsh), achieving equivalence to 
the natural marshes after $\sim 12$ yr (Fig. $4 \mathrm{c}$ ). Stem height was strongly correlated with aboveground biomass ( $r$ $=0.82$ ), suggesting that height is a useful surrogate for aboveground biomass and Spartina production. There was no relationship, however, between stem density and constructed marsh age (Fig. 4d), although constructed marshes generally had more stems per square meter than reference marshes. In constructed marshes, Spartina produced more stems that were shorter as compared to Spartina stems of natural marshes (Fig. 4c, d). Relatively short Spartina canopies have been observed in constructed S. foliosa marshes in southern California (Zedler 1993), and yearly $\mathrm{N}$ additions were needed to consistently produce taller stems that were characteristic of natural marshes in the area (Boyer and Zedler 1998).

In contrast to Spartina, algal biomass as measured by chlorophyll $a$ was unrelated to constructed marsh age. But, when the data were plotted as ratio of constructed marsh to reference marsh, chlorophyll $a$ of epiphytic algae increased with constructed marsh age (Fig. 5a). Chlorophyll $a$ of epiphytic algae approached equivalence to natural marshes after $15 \mathrm{yr}$, roughly the time required for the Spartina canopy (stem height and density) to develop, although we found no correlation between the chlorophyll $a$ of epiphytic algae and Spartina aboveground biomass $(r=0.12)$, stem height ( $r$ $=-0.01)$, or stem density $(r=0.04)$. There was no relationship between percent equivalence of chlorophyll $a$ in surface sediments and constructed marsh age (data not shown). When averaged across all marshes, sediments $\left(4.4 \pm 0.5 \mathrm{mg} / \mathrm{m}^{2}\right.$ [mean $\left.\left.\pm 1 \mathrm{sE}\right]\right)$ and epiphytes $\left(4.2 \pm 1.1 \mathrm{mg} / \mathrm{m}^{2}\right)$ contained similar amounts of chlorophyll $a$, illustrating the importance of both epiphytic and sediment algae to marsh primary production. Percent similarity of diatom species between constructed and reference marshes also increased along the chronosequence (Fig. 5b, c). Minimum similarity index (Gauch 1982) of epiphytic diatoms was 35-46\% in constructed marshes younger than $12 \mathrm{yr}$, increasing to $64-71 \%$ in marshes $13 \mathrm{yr}$ old and older (Fig. 5b). The sediment diatom community was slower to develop than epiphytic diatoms. After 25-30 yr, percent similarity of sediment diatoms in constructed marshes was $\sim 50 \%$ relative to natural marshes (Fig. $5 \mathrm{c}$ ). A total of 362 taxa, mostly diatoms (342), filamentous green algae, and blue-green algae (cyanobacteria), were identified in constructed and natural marshes (L. Zheng, R. J. Stevenson, and C. B. Craft, unpublished manuscript). More taxa (292) were associated with sediments than with epiphytes (225). The most common soft algae genera included the green algae, Enteromorpha and $R h i$ zoclonium, and the cyanobacteria, Ocillatoria and Schizothrix.

Benthic invertebrates.-Density of benthic invertebrates was significantly lower in the 1 - and 3 -yr-old constructed marshes as compared to natural marshes (Fig. 6a). Constructed marshes $>5$ yr old supported

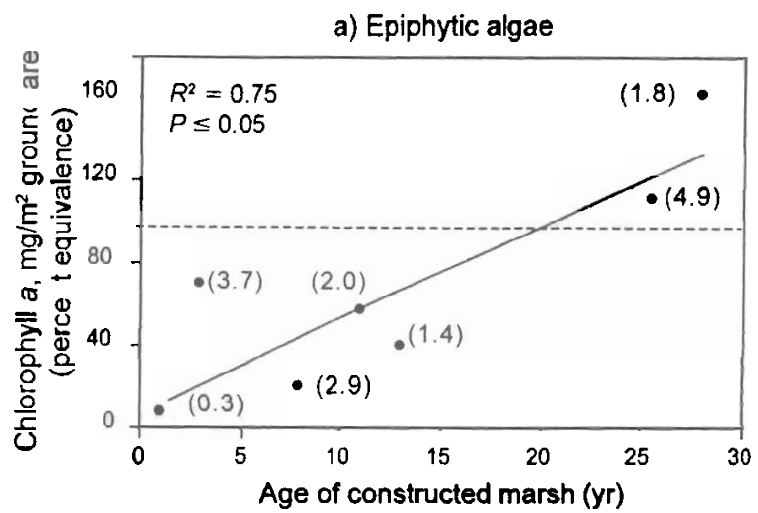

b) Epiphytic diatoms

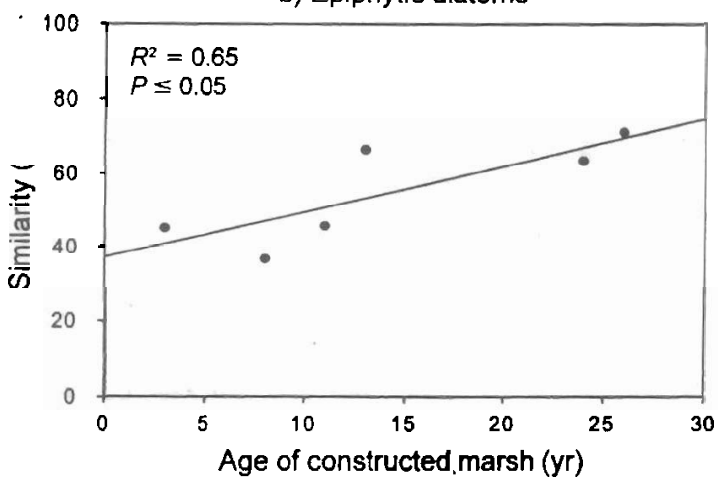

c) Sediment diatoms

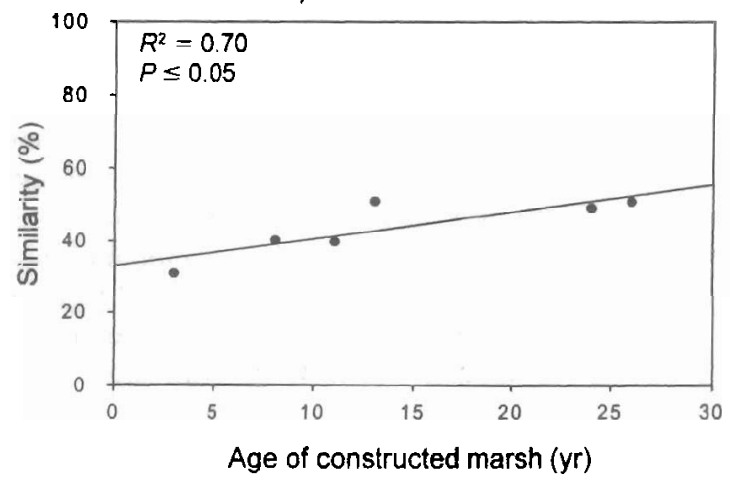

Fig. 5. Percentage equivalence of (a) epiphytic algae chlorophyll $a$ along a chronosequence of constructed salt marshes relative to natural reference marshes. Values in parentheses are chlorophyll $a$ of the constructed marshes in summer 1998. Percent similarity of (b) epiphytic and (c) sediment diatom communities along a chronosequence of constructed salt marshes and natural reference marshes in spring 1998.

invertebrate populations comparable to their natural marsh counterparts. Our findings suggest relatively rapid development of the invertebrate community that contrasts with previous studies of older (up to $16 \mathrm{yr}$ ) constructed marshes (Sacco et al. 1994). Invertebrate density was significantly related to constructed marsh age $\left(R^{2}=0.89, P<0.001\right)$. Young constructed marshes also contained fewer invertebrate taxa than comparable 


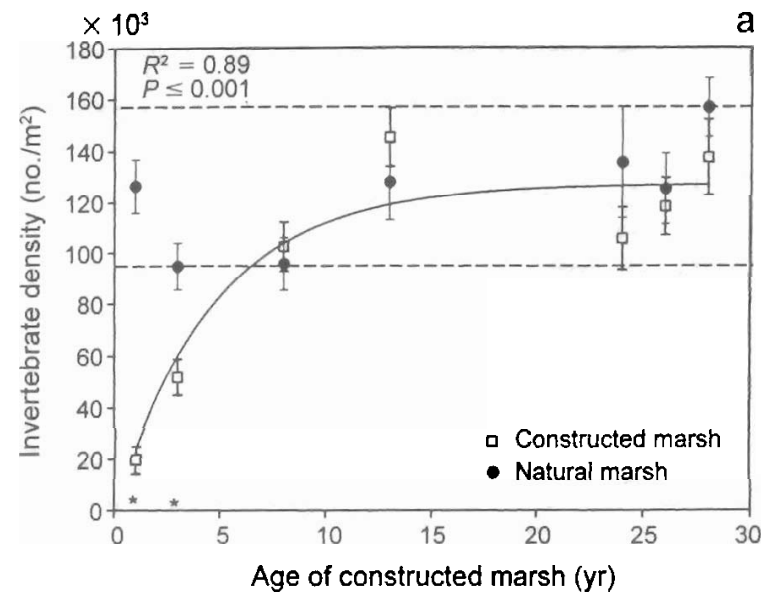

b
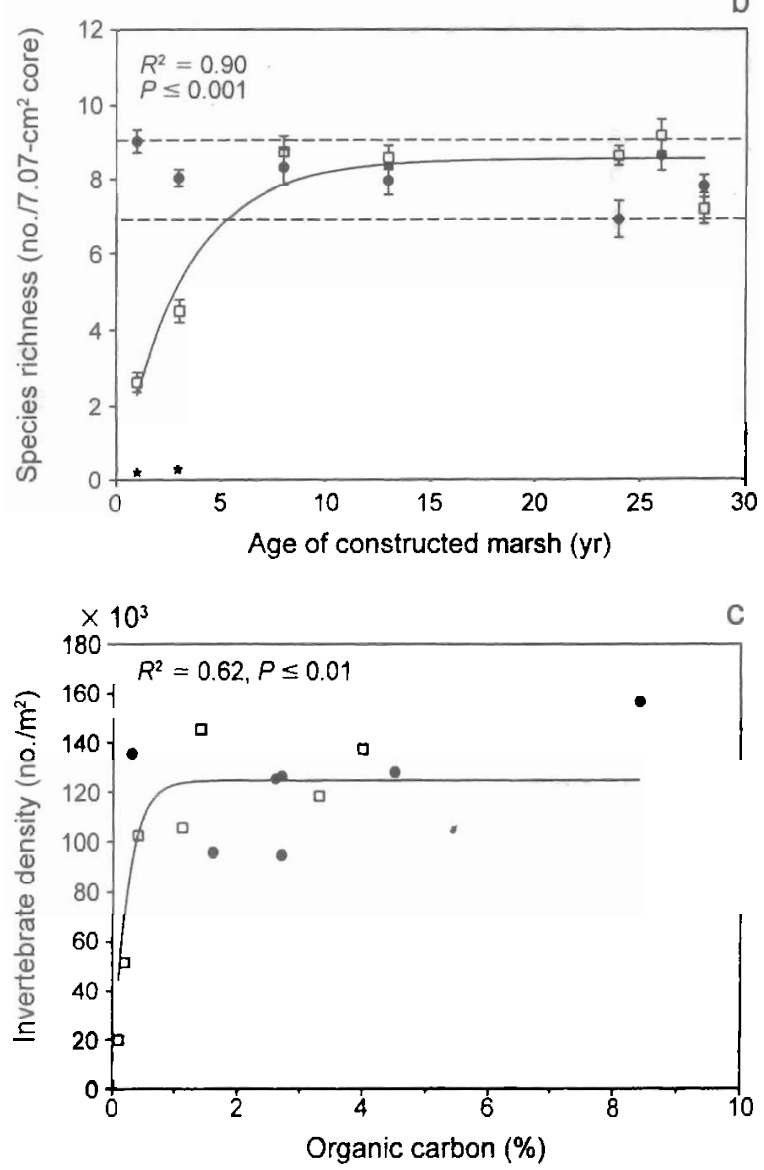

FIG. 6. (a) Density (in thousands per $\mathrm{m}^{2}$ ) and (b) taxa richness (number of taxa per $7.07-\mathrm{cm}^{2}$ core) of benthic invertebrates along a chronosequence oi constructed salt marshes and natural reference marshes. Asterisks $\left({ }^{*}\right)$ indicate that the constructed and paired reference marshes are significantly different $(P \leq 0.05)$ according to Student's $t$ test. Dashed lines represent the range of values measured in the natural marshes. (c) Regression of benthic invertebrate density vs. percent soil organic $\mathrm{C}(0-10 \mathrm{~cm}$ depth) of constructed and natural marshes. reference marshes. Species richness was significantly lower in the 1- and 3-yr-old constructed marshes as compared to natural marshes whereas constructed marshes $>5$ yr old had similar number of taxa as natural marshes (Fig. 6b). Like density, invertebrate taxa richness was strongly related to constructed marsh age $\left(R^{2}\right.$ $=0.90, P<0.001$ ).

Invertebrate density was strongly related to percent soil organic C $\left(0-10 \mathrm{~cm}\right.$ depth) across all marshes $\left(R^{2}\right.$ $=0.62, P<0.0 \mathrm{I} ;$ Fig. $6 \mathrm{c})$. The relationship between invertebrate density and organic $\mathrm{C}$ was even stronger when only constructed marshes were analyzed $\left(R^{2}=\right.$ $0.90, P<0.001)$. However, it appears that a critical or "threshold" concentration of $\sim 0.5 \%$ to $1 \%$ soil organic $\mathrm{C}$ is needed to support the high density of benthic invertebrates found in natural marshes (Fig. $6 \mathrm{c}$ ). Above this threshold concentration, invertebrate densities are relatively uniform across the range from $1 \%$ to $8 \%$ organic C (Fig. 6c).

\section{Structure and function of wetland soils}

Sediment deposition.-Constructed marshes and natural marshes were sinks for suspended sediment although sediment deposition was significantly greater in the 1- and 11-yr-old constructed marshes than in comparable natural marshes (Fig. 7a). There was no difference in sediment deposition between older (24to 28-yr-old) constructed marshes and comparable reference marshes. Similar to this study, higher rates of sedimentation were measured in young (1- to 3-yr-old) constructed S. alterniflora marshes $\left(21-36 \mathrm{~kg} \cdot \mathrm{m}^{-2} \cdot \mathrm{yr}^{-1}\right)$ than in natural reference marshes $\left(<2 \mathrm{~kg} \cdot \mathrm{m}^{-2} \cdot \mathrm{yr}^{-1}\right)$ (Craft 1997). As Spartina becomes established, increasing stem density reduces velocity of tidal water and facilitates deposition of suspended particles (Gleason et al. 1979, Knutson 1988). Over time, sedimentation increased the proportion of fine particles in constructed marsh surface soils. Percentage of silt plus clay $(0-10 \mathrm{~cm}$ depth) increased along the chronosequence of constructed salt marshes $\left(R^{2}=0.53\right.$; Fig. 7b). Young constructed marsh soils were dominated by sand particles $(>90 \%)$, whereas natural marshes and the oldest constructed marshes contained less sand (50-70\%) and more silt and clay.

Element sequestration.-Soil organic $\mathrm{C}$ and $\mathrm{N}$ pools were slow to develop in constructed marshes so that, after $28 \mathrm{yr}$, constructed marshes still contained significantly less soil organic $\mathrm{C}$ and $\mathrm{N}$ than natural marshes (Fig. 8a, b). Only the 24-yr-old constructed marsh contained soil $\mathrm{C}$ and $\mathrm{N}$ similar to its paired reference marsh. In constructed marshes, soil $\mathrm{N}$ and organic $\mathrm{C}$ pools were significantly related to marsh age $\left(R^{2}=\right.$ $0.69-0.80$ ). In contrast to $C$ and $N$, soil $P$ pools generally were larger in the constructed marshes (Fig. 8c). Large amounts of $\mathrm{P}$ in constructed marshes probably reflect greater $P$ sorption and precipitation with $\mathrm{Fe}, \mathrm{Al}$, and $\mathrm{Ca}$ in the low organic matter, high mineral content soils (Craft 1997). Carbon, $N$, and $P$ stored as macro- 

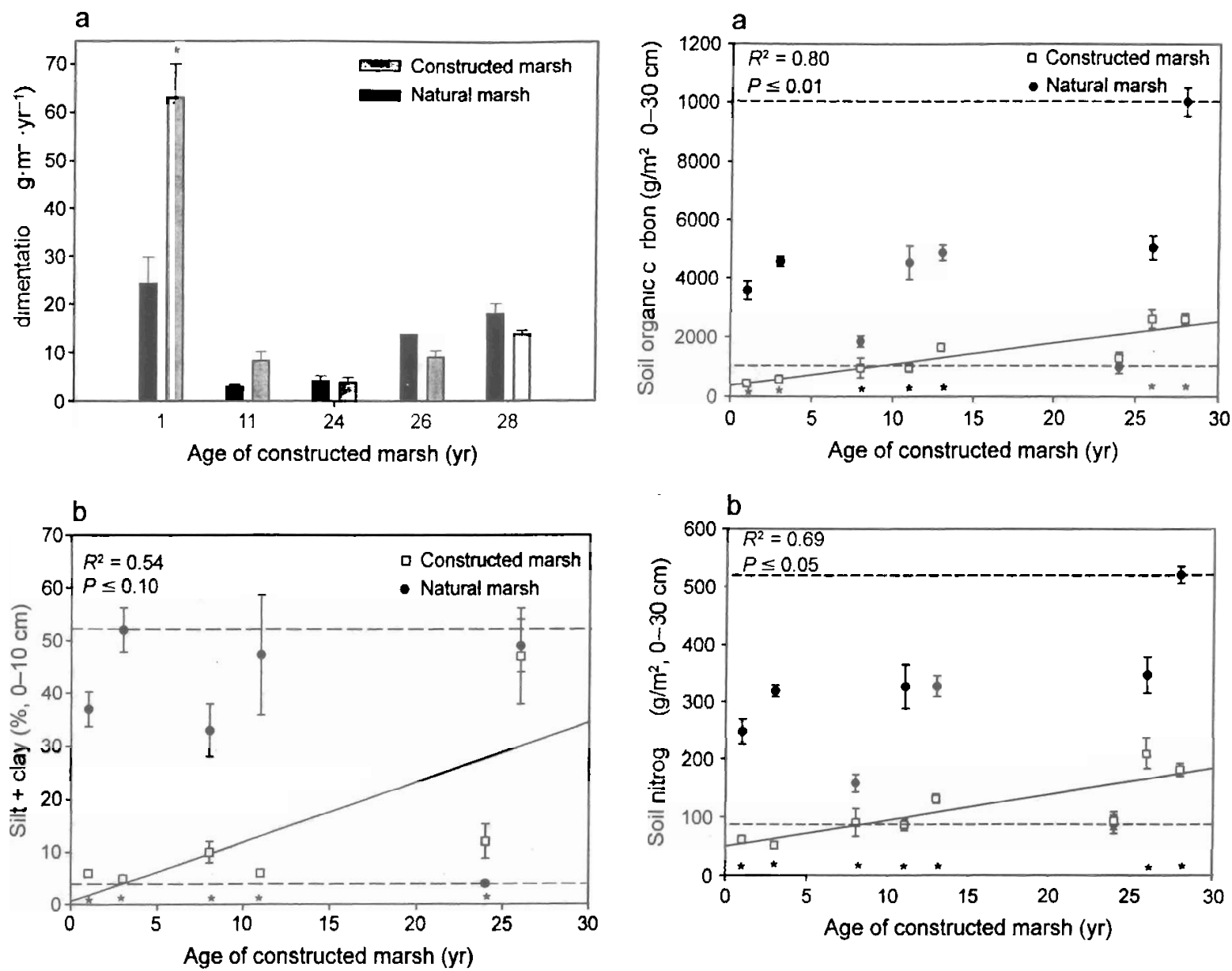

FIG. 7. (a) Sediment deposition and (b) soil silt plus clay $(0-10 \mathrm{~cm}$ depth) along a chronoseauence of constructed salt marshes and natural reference marshes. Asterisks (*) indicate that the constructed and paired reference marshes are significantlv different $(P \leq 0.05)$ according to Student's $t$ test. Dashed lines in (b) represent the range of values measured in the natural marshes. The 13-yr-old constructed marsh (Dill's Creek) was excluded from the analysis because of its terrestrial origin (submerged upland) and, hence, high initial clay content.

organic matter also increased in a predictable manner over time in constructed marshes $\left(R^{2}=0.86-0.92\right.$, data not shown). However, $\mathrm{C}, \mathrm{N}$, and $\mathrm{P}$ stored in MOM was an order of magnitude less as compared to $\mathrm{C}, \mathrm{N}$, and $P$ in soil.

In spite of smaller soil organic $\mathrm{C}$ pools, constructed marshes sequestered $\mathrm{C}$ at rates comparable to $\mathrm{C}$ accumulation in natural marshes. Organic $\mathrm{C}$ accumulation ranged from 18 to $99 \mathrm{~g} \mathrm{C} \cdot \mathrm{m}^{-2} \cdot \mathrm{yr}^{-1}$ in constructed marshes (mean $=42 \mathrm{~g} \mathrm{C} \cdot \mathrm{m}^{-2} \cdot \mathrm{yr}^{-1}$ ) as compared to 0 $115 \mathrm{~g} \mathrm{C} \cdot \mathrm{m}^{-2} \cdot \mathrm{yr}^{-1}$ (mean $=43 \mathrm{~g} \mathrm{C} \cdot \mathrm{m}^{-2} \cdot \mathrm{yr}^{-1}$ based on ${ }^{137} \mathrm{Cs}$, and $40 \mathrm{~g} \mathrm{C} \cdot \mathrm{m}^{-2} \cdot \mathrm{yr}^{-1}$ based on ${ }^{210} \mathrm{~Pb}$ ) in natural marshes (Table 2). The percentage of above- and belowground net primary production (NPP) buried annually also was similar in constructed $(9 \%)$ and natural marshes $(6 \%$ ) (Table 2). Percent NPP buried annually

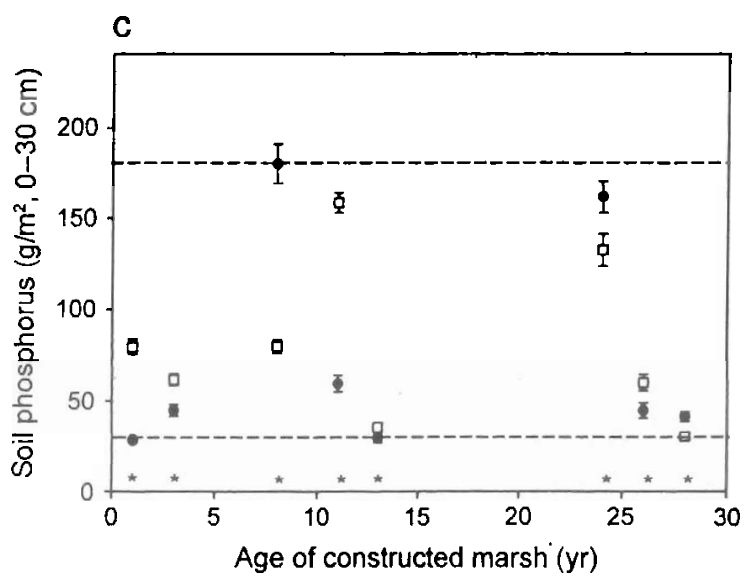

FIG. 8. Soil (a) organic carbon, (b) nitrogen, and (c) phosphorus pools $(0-30 \mathrm{~cm}$ depth) along a chronosequence of constructed salt marshes and natural reference marshes. Asterisks $\left(^{*}\right)$ indicate that the constructed and paired reference marshes are significantly different $(P \leq 0.05)$ according to Student's $t$ test. Dashed lines represent the range of values measured in the natural marshes.

in the 1-yr-old constructed marsh (35\%) was eight times greater as compared to its paired reference marsh (4\%). Among the natural marshes, riverine marshes (Snow's Cur, Swansboro) sequestered proportionally 
TABLE 2. Soil organic carbon, nitrogen, and phosphorus accumulation along a chronosequence of constructed salt marshes and natural reference marshes.

\begin{tabular}{|c|c|c|c|c|c|c|c|}
\hline \multirow[b]{2}{*}{ Marsh } & \multirow{2}{*}{$\begin{array}{c}\text { Age } \\
(\mathrm{yr}) \dagger\end{array}$} & \multicolumn{2}{|c|}{ Organic $C\left(\mathrm{~g} \cdot \mathrm{m}^{-2} \cdot \mathrm{yr}^{-1}\right) \ddagger$} & \multicolumn{2}{|c|}{ Nitrogen $\left(\mathrm{g} \cdot \mathrm{m}^{-2} \cdot \mathrm{yr}^{-1}\right)$} & \multicolumn{2}{|c|}{ Phosphorus $\left(\mathrm{g} \cdot \mathrm{m}^{-2} \cdot \mathrm{yr}^{-1}\right)$} \\
\hline & & Constructed & Natural & Constructed & Natural & Constructed & Natural \\
\hline DOT & 1 & $99(35 \%)$ & $30-36(4-5 \%)$ & 12.5 & $2.3-2.8$ & 5 & $0.3-0.3$ \\
\hline Consultant & 3 & $39(7 \%)$ & $35-51(3-5 \%)$ & 5.5 & $2.6-3.8$ & 0 & $0.5-0.7$ \\
\hline Port & 8 & $27(4 \%)$ & $28-32(3-4 \%)$ & 1.9 & 2.1-2.4 & 0.6 & $1.7-1.9$ \\
\hline Swansboro & 11 & $18(5 \%)$ & $105-115(13-18 \%)$ & 1.3 & $6.2-8.7$ & 0 & $0.5-0.7$ \\
\hline Dill's Creek & 13 & $62(11 \%)$ & $0-2(0-<1 \%)$ & 5.7 & $\mathbf{0}-0.1$ & 0.8 & $0-0.02$ \\
\hline Pine Knoll Shores§ & 24 & $21(2 \%)$ & $\ldots$ & 1.9 & $\ldots$ & 0 & $\ldots$ \\
\hline Marine lab & 26 & $34(4 \%)$ & $0-15(0-2 \%)$ & 2.7 & $0-15$ & 0 & $0-0.02$ \\
\hline Snow's Cut§ & 28 & $39(5 \%)$ & $77(12 \%)$ & 2.6 & 4.0 & 0.2 & 0.5 \\
\hline Mean $\left({ }^{137} \mathrm{Cs}\right) \|$ & & $42 \pm 9(9 \pm 4 \%)$ & $43 \pm 16(6 \pm 3 \%)$ & $4.3 \pm 1.3$ & $3.0 \pm 1.1$ & $0.8 \pm 0.6$ & $0.6 \pm 0.2$ \\
\hline Mean $\left({ }^{210} \mathrm{~Pb}\right)$ & & & $40 \pm 11(6 \pm 2 \%)$ & & $2.8 \pm 0.7$ & & $0.5 \pm 0.2$ \\
\hline
\end{tabular}

Notes: Carbon, $\mathrm{N}$, and $\mathrm{P}$ accumulation of natural marshes was calculated using ${ }^{137} \mathrm{Cs}$ (in bold) and ${ }^{210} \mathrm{~Pb}$. Carbon, $\mathrm{N}$, and

$\mathrm{P}$ accumulation of constructed marshes was calculated as described in Craft et al. (1988) (see Methods section for details).

$\dagger$ Constructed marshes only.

$\ddagger$ Percentage of above- plus belowground net primary production (NPP) buried annually in each marsh is reported in

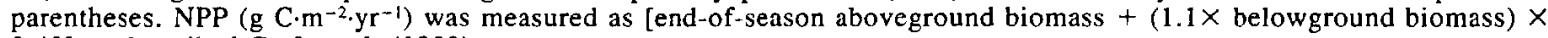
0.401 as described Craft et al. (1999).

$\S$ No ${ }^{137} \mathrm{Cs}$ peak was discernable in the Snow's Cut marsh so only ${ }^{210} \mathrm{~Pb}$ was used to calculate C, N, and $\mathrm{P}$ accumulation. Carbon, N, and $\mathrm{P}$ accumulation were not calculated for the Pine Knoll Shores Marsh because neither ${ }^{137} \mathrm{Cs}$ nor ${ }^{210} \mathrm{~Pb}$ profiles were interpretable.

|| Natural marshes only.

more NPP as soil organic matter (12-13\%) than marshes located on other geomorphic positions (e.g., fringe, flat, submerged uplands; Table 2).

Constructed marsh soils also were sinks for $\mathrm{N}$ and, to a lesser extent, $P$ (Table 2). Nitrogen accumulation in the 1- and 3-yr-old constructed marshes was 1.5 to four times greater $\left(5.5-12.5 \mathrm{~g} \cdot \mathrm{m}^{-2} \cdot \mathrm{yr}^{-1}\right)$ as compared to reference marshes $\left(2.3-3.8 \mathrm{~g} \mathrm{~N} \cdot \mathrm{m}^{-2} \cdot \mathrm{yr}^{-1}\right)$. The mean rate of $\mathrm{N}$ accumulation in constructed marshes was 4.3 $\mathrm{g} \cdot \mathrm{m}^{-2} \cdot \mathrm{yr}^{-1}$ as compared to $2.8\left({ }^{210} \mathrm{~Pb}\right)$ to $3.0 \mathrm{~g} \cdot \mathrm{m}^{-2} \cdot \mathrm{yr}^{-1}$ $\left({ }^{137} \mathrm{Cs}\right)$ for reference marshes. Greater $\mathrm{N}$ accumulation in constructed marshes relative to natural marshes reflects strong $\mathrm{N}$ limitation and efficient retention of this element in these wetlands (Craft et al. 1999). With the exception of the 1-yr-old constructed marsh, which had

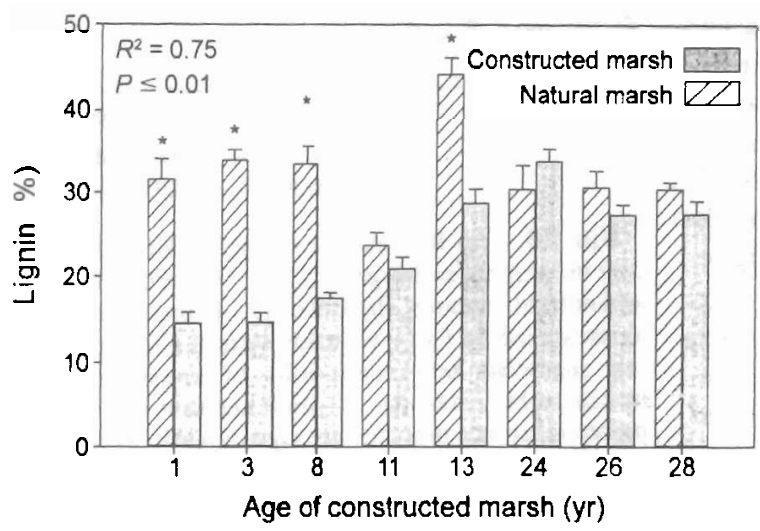

Fig. 9. (a) Lignin content of accumulating macro-organic matter $(0-10 \mathrm{~cm}$ depth) along a chronosequence of constructed salt marshes and natural reference marshes. Asterisks $\left({ }^{*}\right)$ indicate that the constructed and paired reference marshes are significantly different $(P \leq 0.05)$ according to Student's $t$ test. the highest rate of $\mathrm{P}$ accumulation $\left(5 \mathrm{gm}^{2} / \mathrm{yr}\right), \mathrm{P}$ accumulation in constructed and natural marshes was $<2$ $\mathrm{g} \cdot \mathrm{m}^{-2} \cdot \mathrm{yr}^{-1}$. Rates of $\mathrm{N}$ and $\mathrm{P}$ accumulation measured in our marshes are within the range reported for other natural, constructed, and restored salt marshes (Craft et al. 1999, Craft 2001).

Not only did young constructed marshes sequester carbon at rates comparable to or exceeding that of natural marshes, but accumulating organic matter was of higher "quality" in these marshes as compared to older constructed marshes and natural marshes. In constructed marshes $<20$ yr old, accumulating macro-organic matter (MOM) contained more labile organic compounds (54-62\% water-soluble extractives) and less recalcitrant material (14-34\% lignin) than reference marshes (36-53\% extractives and $24-44 \%$ lignin). Lignin content of MOM increased with constructed marsh age $\left(R^{2}=0.75\right.$; Fig. 9$)$, whereas water-soluble extractives decreased with marsh age $\left(R^{2}=0.63\right.$, data not shown). Two frequently used indices of organic matter quality, lignin:N, and lignin:cellulose index (LCI; Melillo et al. 1982, Updegraff et al. 1995), also increased with constructed marsh age (lignin:N, $R^{2}=0.66, P \leq$ 0.05 ; LCI, $R^{2}=0.63, P \leq 0.05$; data not shown). Lignin: $N$ of young constructed marsh MOM was low (1524 ) as compared to older constructed marshes (30-44) and natural marshes (29-46). Likewise, LCI was lower in young constructed marshes $(0.24-0.39)$ than in older constructed marshes (0.45-0.63) and natural marshes $(0.50-0.71)$.

In constructed marshes, the abundance of easily decomposable compounds in accumulating organic matter reflects the higher proportion of live roots in MOM as compared to natural marshes that contain more dead roots and decomposed organic matter. These data are 
consistent with our observation that a greater proportion of the soil organic matter pool is labile, based on carbon mineralization (see Fig. 10c), in constructed vs. natural marshes. There is a trade-off, however, between organic matter quality and $C$ sequestration in soil such that young constructed marshes, with high quality, decomposable MOM, may be less effective in sequestering carbon over the long-term than natural marshes.

Microbial processes. - There was a significant relationship between anaerobic decomposition and percent soil organic $C$ at the $0-10 \mathrm{~cm}$ depth $\left(R^{2}=0.69\right.$ for all marshes, $R^{2}=0.95$ for constructed marshes only; Fig. 10a), underscoring the importance of accumulating soil organic carbon for sustaining heterotrophic microbial activity. Soil organic $\mathrm{C}$ mineralization increased with age of the constructed marshes (Fig. 10b). Anaerobic decomposition in the 1-, 3-, and 11-yr-old constructed marshes was significantly lower than in natural marshes. Except for the 26-yr-old constructed marsh, mineralization was highest in natural marshes with the highest soil organic $\mathrm{C}$ content. In constructed marshes, organic matter mineralization achieved equivalence to natural marshes after soil organic $\mathrm{C}$ accumulated to $0.5-1 \%(0-10 \mathrm{~cm}$ depth $)$ or $1000 \mathrm{~g} / \mathrm{m}^{2}(0-30 \mathrm{~cm}$ depth).

When $\mathrm{C}$ mineralization data were expressed as $\mathrm{CO}_{2}$ evolution per gram of soil organic carbon, $\mathrm{CO}_{2}$ evolution was higher in the constructed marshes than in the corresponding natural marshes. For example, if constructed and natural marshes had similar $\mathrm{CO}_{2}$ evolution per gram of soil organic $\mathrm{C}$, the ratio of constructed marsh $\mathrm{CO}_{2}$ to natural marsh $\mathrm{CO}_{2}$ would fall along a 1:1 line (see Fig. 10c). Anaerobic incubations of marsh soils, however, revealed that the ratio of $\mathrm{CO}_{2}$ evolution in young ( $<5 \mathrm{yr}$ old) and intermediate (515 yr old) age constructed marshes vs. natural marshes lay mostly above the 1:1 line (Fig. 10c). These results indicate that, in young and intermediate age constructed marshes, decomposition of soil organic matter is more efficient than in older constructed marshes and natural marshes. Our results suggest that, in spite of low soil organic $C$ and correspondingly low decomposition rate, young constructed marsh soils possess higher heterotrophic metabolism per unit of organic $\mathrm{C}$ than older natural marshes. Enhanced carbon metabolism in constructed marshes likely is due to higher quality accumulating macro-organic matter (see Fig. 9a), greater tidal flushing, and, possibly, better aeration of sandy constructed marsh soils as compared to finetexture natural marsh soils ( $R$. Freese, unpublished data).

\section{Conceptual Model of Salt Marsh ECOSYSTEM DEVELOPMENT}

Ecological attributes describing constructed marsh ecosystem development exhibited three distinct trajectories. Processes linked to hydrology, such as sedimentation and organic $\mathrm{C}$ and $\mathrm{N}$ accumulation in soil,
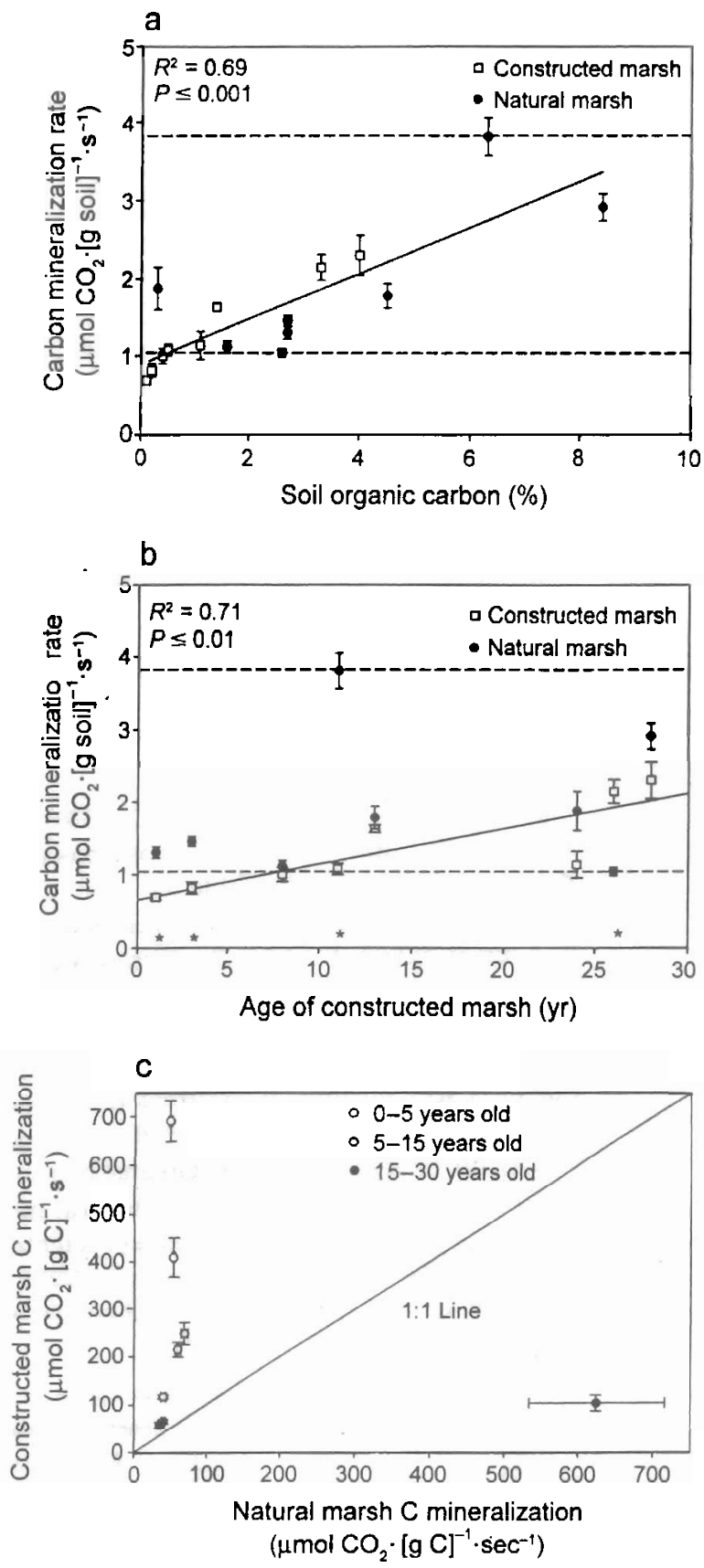

FIG. 10. (a) Regression of anaerobic carbon mineralization vs. percent soil organic $\mathrm{C}(0-10 \mathrm{~cm}$ depth) of constructed and natural marshes. (b) Decomposition of soil organic matter as measured by $\mathrm{CO}_{2}$ evolution $\left(\mu \mathrm{mol} \mathrm{CO} \mathrm{CO}_{2} \cdot[\mathrm{g} \text { soil }]^{-1} \cdot \mathrm{s}^{-1}\right)$ during anaerobic lab incubations of constructed and natural marsh soils. Asterisks $\left({ }^{*}\right)$ indicate that the constructed and paired reference marshes are significantly different $(P \leq 0.05)$ according to Student's $t$ test. Dashed lines represent the range of values measured in the natural marshes. (c) $\mathrm{CO}_{2}$ evolution ( $\mu \mathrm{mol} \mathrm{CO} \cdot[\mathrm{g} \mathrm{C}]^{-1} \cdot \mathrm{s}^{-1}$ ) of constructed vs. paired natural salt marsh soils (means $\pm 1 \mathrm{SE}$ ). If constructed and natural marshes possess similar rates of decomposition, the ratio of constructed marsh $\mathrm{CO}_{2}$ to natural marsh $\mathrm{CO}_{2}$ will fall along a 1 : 1 line. 


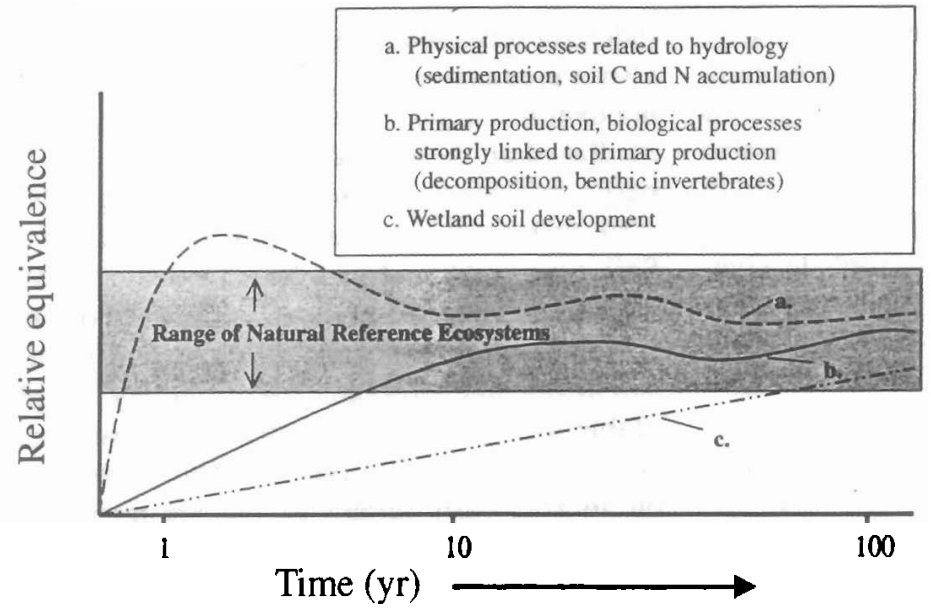

Fig. 11. Trajectories describing changes in functional and structural attributes during salt marsh ecosystem development. Trajectory "a" describes processes linked to hydrology (sedimentation, soil organic $\mathrm{C}$ and $\mathrm{N}$ accumulation) as well as organic matter quality and Spartina stem density. Trajectory " $b$ " describes attributes of biological processes strongly linked to primary production (consumer and heterotrophic activity). Trajectory " $c$ " describes wetland soil development (soil organic $\mathrm{C}$ and $\mathrm{N}$ pools) and diatom community similarity. achieved or exceeded equivalence to natural marshes almost immediately following construction (Fig. 11, trajectory “a”). Processes linked to hydrology are initially rapid because they are the direct result of grading the sites to elevations that are lower than natural marshes. This is especially true along the marsh-open water interface where constructed marshes lack the higher elevation streamside levee that is common to most natural marshes (R. Freese, unpublished data).

Biological processes such as primary production and heterotrophic activity increased gradually over time, converging to equivalence to natural marshes after 515 years (Fig. 11, trajectory "b"). Spartina aboveground biomass and invertebrate density achieved equivalence within 8 to 13 years following construction. Macro-organic matter, stem height and density, and algal biomass developed somewhat slower, achieving equivalence to natural marshes after $\sim 12-20$ years. Biogeochemical processes dependent on soil organic $\mathrm{C}$ (e.g., decomposition) also exhibited this type of trajectory, converging to equivalenice after 5-15 years.

Some ecological attributes did not achieve equivalence to natural marshes even after 28 years (Fig. 11 , trajectory "c"). Constructed marsh soils consistently contained less organic $\mathrm{C}$ and $\mathrm{N}$ in the top $30 \mathrm{~cm}$ depth than natural marshes regardless of age. This result may reflect differences in the quality of accumulating soil organic matter or physical properties that affect organic carbon protection. For example, greater hydraulic conductivity of the sandy-textured, constructed marsh soils may cause organic matter to decompose faster as compared to natural marsh soils that contain more silt and clay particles. Conversely, soil organic $\mathrm{C}$ and $\mathrm{N}$ pools $(0-30 \mathrm{~cm})$ may take longer to develop than the 28 -yr period of record represented by our constructed marsh chronosequence.

Like soil $\mathrm{C}$ and $\mathrm{N}$ pools, similarity of constructed marsh epiphytic and sediment diatom communities also did not achieve $100 \%$ equivalence to natural marshes during the first 28 years. There was, however, a trend of increasing similarity over time as similarity index of epiphytic diatoms approached $70 \%$ after 28 years. But, in the case of sediment diatoms, similarity index was only $50 \%$ after 28 years following marsh construction. One would not expect $100 \%$ similarity of diatom communities between constructed and natural marshes or between two natural marshes for that matter. Natural freshwater wetlands with the same hydrology and vegetation exhibit diatom similarity on the order of $60-$ $70 \%$ (J. Stevenson, unpublished data). These data suggest that, after $\sim 15$ years, our constructed marshes probably contain diatom assemblages that are comparable to natural salt marshes in the area.

From our study, it is apparent that trajectories exist to describe ecosystem development of certain ecological attributes following salt marsh construction. Trajectories describing development of Spartina biomass, soil organic matter $(C, N)$, and benthic invertebrate density were previously reported for two of the constructed marshes (Pine Knoll Shores, Snow's Cut) based on periodic measurements of over a 25-year period (Craft et al. 1999). Similarly, trajectories describing development of macrophyte biomass (Spartina cynosuroides, Juncus roemerianus) and wetland soil characteristics over a 15-year period were reported for a constructed brackish-water estuarine marsh in North Carolina (Craft et al. 2002).

In contrast, ecological attributes of constructed estuarine marshes along the U.S. Pacific coast fail to exhibit directional trends with time or exhibit only weak trajectories following marsh construction (Simenstad and Thom 1996, Zedler and Callaway 1999). In two west coast marshes (southern California, Washington), soil organic matter and $\mathrm{N}$ exhibited a weak increase with marsh age, whereas attributes of the macrophyte and benthic invertebrate community were unrelated to marsh age, even $7-12$ years after marsh construction (Simenstad and Thom 1996, Zedler and Callaway 1999). For some attributes such as benthic invertebrates and soils, the period of record ( $7-12$ years) 
probably was too short to identify trajectories. Aboveground biomass and soils in the Spartina patens community in the brackish-water marsh in North Carolina also never achieved equivalence to the natural marsh because of infrequent tidal inundation (Craft et al. in 2002). For the constructed marshes, the lack of identifiable trajectories to describe the macrophyte community even after 7 to 15 years suggests that these marshes may never achieve full or complete equivalence to the natural marsh "target" (Zedler and Callaway 1999).

Since hydrologic forcing drives wetland ecosystem development, the slow rate of ecosystem development reported for some constructed marshes may result from infrequent and unpredictable delivery of freshwater, sediment, and nutrients. The west coast marshes are characterized by high interannual variability with respect to flood pulses (Zedler 2001) that results in high interannual variability of measurements (of biomass and stem height), making it difficult to identify trajectories (Zedler and Callaway 1999). Furthermore, seasonal (November-March) inputs of freshwater and hypersaline ( $>40 \mathrm{ppt}$ ) soil conditions (Zedler 2001) may slow the growth of Spartina and, hence, the rate of ecosystem development as compared to southeastern U.S. marshes where rainfall is greater and evenly distributed throughout the year. Comparison of west coast vs. east coast marshes revealed that constructed (192 $\left.\mathrm{g} / \mathrm{m}^{2}\right)$ and natural $\left(453 \mathrm{~g} / \mathrm{m}^{2}\right)$ marshes in southern California contained less Spartina biomass than marshes in North Carolina (constructed marsh $=713 \mathrm{~g} / \mathrm{m}^{2}$, natural marsh $=992 \mathrm{~g} / \mathrm{m}^{2}$ ) (Langis et al. 1991, Craft et al. 1999). In this study, our 3-yr-old constructed marsh contained three times more biomass $\left(671 \mathrm{~g} / \mathrm{m}^{2}\right)$ than a 4-yr-old $S$. foliosa marsh in southern California (192 $\mathrm{g} / \mathrm{m}^{2}$ ) (Langis et al. 1991).

Human alteration of the surrounding landscape and watershed, as is the case in southern California, also may slow ecosystem development and potential for restoration (National Research Council 1992). Many marsh mitigation projects are located in urban environments where initial conditions, such as altered hydrology and invasive species, interfere with ecosystem development (Zedler and Callaway 1999). The coastal landscape of North Carolina is less degraded than that of southern California, so initial conditions probably are more favorable for ecosystem development to occur and for trajectories to be discerned.

\section{INDICATORS OF STRUCTURAL AND FunCTIONAL EQUIVALENCE}

There is much interest in identifying indicators or performance criteria that can be used to assess functional and structural equivalence of wetland creation and restoration projects (Streever 2000, National Research Council 2001, Zedler 2001). The ideal indicator is one that accurately describes other attributes of ecosystem function and structure and, so, serves as an index for other ecological attributes. The ideal indicator also is predictable (i.e., it changes in a predictable manner over time), easy to measure, and inexpensive (Table 3). Based on these criteria, several soil- and Spartinabased indicators are useful for assessing full or complete restoration of created and restored salt marshes. Soil organic C, and to a lesser extent, MOM and N, were significantly correlated with heterotrophic activity (decomposition, benthic invertebrates) and wetland soil development (organic matter quality, silt plus clay) (Table 4), and ecological attributes were more highly correlated when soil organic $\mathrm{C}$ and $\mathrm{N}$ were expressed on an area basis (grams per square meter, $0-30 \mathrm{~cm}$ ) rather than a mass basis (percentage, $0-10 \mathrm{~cm}$ ) (Table 4). Characteristics of aboveground Spartina were not as strongly correlated with other ecological attributes as soil organic C and MOM (Table 4). Soil organic C is an excellent surrogate for heterotrophic activity, and it is much easier to measure than decomposition rate or benthic invertebrate community composition. It should be noted that, for benthic invertebrates, a threshold amount of organic $\mathrm{C}(0.5-1 \%)$ is needed to support densities comparable to natural marshes. Above this threshold, invertebrate numbers are relatively uniform up to $8 \% \mathrm{C}$, the highest $\mathrm{C}$ content reported for our natural marshes. Anaerobic $\mathrm{C}$ mineralization, on the other hand, increased linearly with soil organic C, suggesting that decomposition is not restricted by a threshold $\mathrm{C}$ concentration. Soil $\mathrm{N}$ is important because it represents ecosystem $\mathrm{N}$ capital, but, because most soil $\mathrm{N}$ is bound in organic $\mathrm{C}$ compounds in fairly fixed ratios, its abundance usually tracks that of organic $\mathrm{C}$. Surprisingly, $\mathrm{N}$ was not correlated with measures of Spartina aboveground production (Table 4). Both C and $\mathrm{N}$ were predictable, relatively easy to use and inexpensive (Table 3). It is interesting to note that most ecological attributes required 5-15 years to achieve equivalence to natural marshes, the amount of time required to accumulate $1000 \mathrm{~g}$ organic $\mathrm{C} / \mathrm{m}^{2}$ and 100 $\mathrm{g} \mathrm{N} / \mathrm{m}^{2}$ in the soil. Soil nutrient pools of $1000 \mathrm{~g} \mathrm{C} / \mathrm{m}^{2}$ and $100 \mathrm{~g} \mathrm{~N} / \mathrm{m}^{2}$ also represent the lowest pools measured in our reference marsh soils (Fig. 8a, b). Bradshaw (1983) suggested that restoration of terrestrial ecosystems required a minimum of $100 \mathrm{~g} \mathrm{~N} / \mathrm{m}^{2}$ to support a productive, self-sustaining plant community.

In southern California, constructed $S$. foliosa marshes often fail to achieve equivalence because low $\mathrm{N}$ slows or arrests ecosystem development (Gibson et al. 1994, Ledler 1996a). Nitrogen additions stimulate growth of Spartina foliosa, but annual additions are needed to maintain tall stems and high levels of biomass (Boyer and Zedler 1998). Gibson et al. (1994) added $1500 \mathrm{~g} \mathrm{C} / \mathrm{m}^{2}$ and up $107 \mathrm{~g} \mathrm{~N} / \mathrm{m}^{2}$ as alfalfa plus ammonium sulfate to accelerate ecosystem development of S. foliosa marshes. At the end of the experiment (20 mo), only $320 \mathrm{~g} \mathrm{C} / \mathrm{m}^{2}$ and $36 \mathrm{~g} \mathrm{~N} / \mathrm{m}^{2}(0-8 \mathrm{~cm}$ depth) was recovered in the soil and less than $5 \%$ was 
TABLE 3. Ecological attributes used to assess ecosystem development and structural/functional equivalence to natura marshes.

\begin{tabular}{|c|c|c|c|c|}
\hline \multirow[b]{2}{*}{ Ecological attribute } & \multirow{2}{*}{$\begin{array}{l}\text { Time required } \\
\text { to achieve } \\
\text { equivalence }(\mathrm{yr})\end{array}$} & \multicolumn{3}{|c|}{ Indicator status } \\
\hline & & Predictable $\dagger$ & Easy to use & Inexpensive \\
\hline \multicolumn{5}{|l|}{ Producers and consumers } \\
\hline Spartina aboveground biomass & $5-10$ & yes $(0.53-0.87)$ & yes & yes \\
\hline Spartina macro-organic matter (MOM) & 15 & yes $(0.88)$ & no & yes \\
\hline Spartina stem density & $5-15$ & no & yes & yes \\
\hline Spartina stem height & $10-15$ & yes $(0.50-0.70)$ & yes & yes \\
\hline Algae chlorophyll $a$ (epiphytic) $\ddagger$ & 15 & yes $(0.81)$ & no & no \\
\hline Algae chlorophyll $a$ (sediment) $\ddagger$ & $\ldots$ & no & no & no \\
\hline Diatom similarity (epiphytic)t & $>30$ & yes $(0.66)$ & no & no \\
\hline Diatom similarity (sediment) $\ddagger$ & $>30$ & yes $(0.71)$ & no & no \\
\hline Benthic invertebrate density & $5-10$ & yes $(0.89)$ & no & no \\
\hline Benthic invertebrate diversity & $5-10$ & yes $(0.90)$ & no & no \\
\hline \multicolumn{5}{|l|}{ Wetland soils } \\
\hline Sediment deposition $\S$ & instantaneous & $\cdots$ & no & no \\
\hline \multicolumn{5}{|l|}{ Element sequestration } \\
\hline Soil organic $C$ pools $(0-30 \mathrm{~cm})$ & $>30$ & yes $(0.80)$ & yes & yes \\
\hline Soil $\mathrm{N}$ pools $(0-30 \mathrm{~cm})$ & $>30$ & yes $(0.69)$ & yes & yes \\
\hline Organic $\mathrm{C}$ and $\mathrm{N}$ accumulation $\$$ & instantaneous & ... & no & no \\
\hline Organic matter quality (lignin)§ & $5-15$ & yes $(0.75)$ & no & no \\
\hline \multicolumn{5}{|l|}{ Microbial processes } \\
\hline Carbon mineralization & $5-15$ & yes $(0.71)$ & no & no \\
\hline
\end{tabular}

$\dagger$ Goodness of fit $\left(R^{2}\right)$ of the regression between the ecological attribute and constructed marsh age.

$\ddagger$ Ratio of constructed marsh to reference marsh.

$\S$ Attributes that perform at a higher level in young constructed marshes as compared to older constructed marshes and natural marshes.

recovered in aboveground biomass (Gibson et al. 1994).

In southern California, reduced $\mathrm{N}$ sequestration in constructed marsh soils may be due to greater decom- position of soil organic matter as compared to marshes of the southeastern U.S. Natural marshes in southern California generaliy contain less soil organic matter (5$10 \%$ ) than natural marshes elsewhere where soil or-

TABLE 4. Pearson correlation coefficients of "candidate" indicators of constructed salt marsh structural and functional equivalence.

\begin{tabular}{|c|c|c|c|c|c|c|c|}
\hline & \multirow{2}{*}{$\begin{array}{c}\text { Aboveground } \\
\text { biomass } \\
\left(\mathrm{g} / \mathrm{m}^{2}\right)\end{array}$} & \multirow{2}{*}{$\underset{\left(\mathrm{g} / \mathrm{m}^{2}\right) \dagger}{\mathrm{MOM}}$} & \multirow{2}{*}{$\begin{array}{l}\text { Stem } \\
\text { height } \\
(\mathrm{cm})\end{array}$} & \multicolumn{2}{|c|}{ Organic $\mathrm{C}$} & \multicolumn{2}{|c|}{ Nitrogen } \\
\hline & & & & $\left(\mathrm{g} / \mathrm{m}^{2}\right) \dagger$ & $(\%) \ddagger$ & $\left(\mathrm{g} / \mathrm{m}^{2}\right) \dagger$ & $(\%) \ddagger$ \\
\hline \multicolumn{8}{|l|}{ Producers and consumers } \\
\hline Aboveground biomass & $\cdots$ & & $\ldots$ & $\ldots$ & $\ldots$ & & \\
\hline Macro-organic matter (MOM) & 0.64 & $\cdots$ & $\cdots$ & $\cdots$ & $\cdots$ & & \\
\hline Stem height & 0.82 & 0.68 & $\cdots$ & $\cdots$ & $\ldots$ & $\ldots$ & $\cdots$ \\
\hline Stem density & 0.04 & -0.08 & -0.07 & -0.24 & -0.21 & -0.20 & -0.19 \\
\hline Chlorophyll $a$ (epiphytes) & 0.12 & -0.38 & -0.01 & -0.41 & -0.48 & -0.35 & -0.47 \\
\hline Chlorophyll $a$ (sediment) & -0.10 & 0.34 & -0.20 & 0.22 & 0.16 & 0.25 & 0.11 \\
\hline Similarity (epiphytes) & 0.55 & 0.62 & 0.35 & 0.82 & 0.82 & 0.74 & 0.73 \\
\hline Similarity (sediment) & 0.56 & 0.71 & 0.29 & 0.82 & 0.63 & 0.77 & 0.63 \\
\hline Invertebrate density & 0.64 & 0.71 & 0.55 & 0.80 & 0.68 & 0.74 & 0.61 \\
\hline Invertebrate richness & 0.82 & 0.57 & 0.53 & 0.63 & 0.47 & 0.61 & 0.42 \\
\hline \multicolumn{8}{|l|}{ Wetland soils } \\
\hline Silt + clay & 0.54 & 0.58 & 0.37 & 0.93 & 0.91 & 0.94 & 0.89 \\
\hline Organic $C\left(\mathrm{~g} / \mathrm{m}^{2}\right)$ & 0.67 & 0.89 & 0.65 & $\ldots$ & $\ldots$ & $\ldots$ & $\ldots$ \\
\hline Organic C $(\%)$ & 0.60 & 0.91 & 0.70 & 0.97 & $\ldots$ & $\cdots$ & \\
\hline Nitrogen $\left(\mathrm{g} / \mathrm{m}^{2}\right)$ & 0.63 & 0.82 & 0,58 & 0.98 & 0.94 & $\cdots$ & \\
\hline Nitrogen $(\%)$ & 0.57 & 0.85 & 0.65 & 0.96 & 0.99 & 0.96 & $\cdots$ \\
\hline Organic matter quality (lignin) & 0.72 & 0.70 & 0.50 & 0.70 & 0.60 & 0.62 & 0.51 \\
\hline $\mathrm{C}$ mineralization & 0.58 & 0.87 & 0.61 & 0.99 & 0.98 & 0.97 & 0.96 \\
\hline
\end{tabular}

Notes: Coefficients were calculated from the mean values of the constructed marshes $(n=8$, except for $n=6$ [diatom similarity] and $n=7[\mathrm{Chl} a$, silt + clay, invertebrates]). Coefficients in bold are significant at $P<0.05$.

$+0-30 \mathrm{~cm}$ depth.

$\ddagger 0-10 \mathrm{~cm}$ depth 
ganic matter may range from $10-40 \%$ (Craft et al. 1999, Callaway 2001). Mild temperatures throughout the year may accelerate decomposition, with resultant low soil organic matter and $\mathrm{N}$ pools (Callaway 2001). Another factor that may reduce soil organic matter stocks in southern California marshes is episodic sedimentation from winter storms that dilute surface soil organic matter pools with mineral sediment (Callaway 2001). Also, the amount of Spartina biomass produced in southern California marshes is less as compared to marshes of the southeastern U.S. (Langis et al. 1991, Craft et al. 1999) so that less detritus is added to the soil.

\section{ConCLUSIONS}

Most attributes of salt marsh structure and function developed in a predictable manner over time following marsh construction. Ecological attributes exhibited two general trajectories during ecosystem development: (1) Processes related to hydrology, such as sedimentation and soil organic $\mathrm{C}$ and $\mathrm{N}$ accumulation, developed almost instantaneously following marsh construction. (2) Attributes linked to heterotrophic processes tracked the development of soil organic $\mathrm{C}$ pools and gradually increased to convergence over time. Primary producers (Spartina, epiphytic algae) and heterotrophic activity (decomposition, benthic invertebrates) converged to equivalence within 5-15 years following marsh construction. Development of wetland soil organic $\mathrm{C}$ and $\mathrm{N}$ pools $(0-30 \mathrm{~cm}$ depth) did not achieve equivalence to natural marshes within the first 28 years following marsh construction. Soil organic $\mathrm{C}$ is ideal for describing the development of salt marsh structure and function following marsh construction. It is predictable, easy to use, inexpensive, and accurately describes development of other ecological attributes. Most ecological attributes required 5-15 years to achieve equivalence to natural marshes, the time needed to accumulate $1000 \mathrm{~g} \mathrm{C} / \mathrm{m}^{2}$ and $100 \mathrm{~g} \mathrm{~N} / \mathrm{m}^{2}$ in the soil. Once $\mathrm{C}$ and $\mathrm{N}$ accumulate to these levels, constructed marshes provided sustainable ecosystem services comparable to services provided by natural marshes.

\section{ACKNOWLEDGMENTS}

Bill Casey and Connie Chiang performed lab analysis. Berry Penhallegan, Gretchenn Anglin, and Casey Day prepared samples for analysis and picked invertebrates. Angela Sturdevant and Mollie McIntosh performed statistical analysis and prepared graphs. Jan Vymazal reviewed an earlier version of the manuscript. We are grateful to all of them and to others we unintentionally overlooked.

This research was supported by a grant from the U.S. Environmental Protection Agency's Science To Achieve Results (STAR) program through grant \#826111-01-0. Although the research described in the article has been funded wholly or in part by the U.S. Environmental Protection Agency's Science To Achieve Results (STAR) program through grant \#826111-01-0, it has not been subjected to any EPA review and therefore does not necessarily reflect the views of the Agency, and no official endorsement should be inferred.
S. W. Broome was involved in design, construction, and monitoring of the six constructed marshes established during the period 1970 and 1990.

\section{Literature Cited}

Aronson, J., S. Dhillion, and E. Le Floc'h. 1995. On the need to select an ecosystem of reference, however imperfect: a reply to Pickett and Parker. Restoration Ecology 3:1-3.

Aronson, J., E. Le Floc'h, C. Foret, C. Ovalle, and R. Pontanier. 1993a. Restoration and rehabilitation of degraded ecosystems in arid and semiarid regions. I. A view from the south. Restoration Ecology 1:8-17.

Aronson, J., E. Le Floc'h, C. Foret, C. Ovalle, and R. Pontanier. $1993 \mathrm{~b}$. Restoration and rehabilitation of degraded ecosystems in arid and semiarid regions. II. Case studies in Chile, Tunisia and Cameroon. Restoration Ecology 1: 168-187.

Boyer, K. E., and J. B. Zedler. 1998. Effects of nitrogen additions on the vertical structure of a constructed cordgrass marsh. Ecological Applications 8:692-705.

Bradshaw, A. D. 1983. The reconstruction of ecosystems. Journal of Applied Ecology 20:1-17.

Brinson, $M$. M., and R. Rheinhardt. 1996. The role of reference wetlands in functional assessment and mitigation. Ecological Applications 6:69-76.

Broome, S. W., E. D. Seneca, and W. W. Woodhouse, Jr. 1988. Tidal salt marsh restoration. Aquatic Botany 32:1-22.

Cahoon, D. R. 1994. Recent accretion in two managed marsh impoundments in coastal Louisiana. Ecological Applications 4:166-176.

Callaway, J. C. 2001. Hydrology and substrate. Pages 89117 in J. B. Zedler, editor. Handbook for restoring tidal wetlands. CRC Press, Boca Raton, Florida, USA.

Craft, C. B. 1997. Dynamics of nitrogen and phosphorus retention during wetland ecosystem succession. Wetlands Ecology and Management 4:177-187.

Craft, C. B. 2001. Soil organic carbon, nitrogen and phosphorus as indicators of recovery in restored Spartina marshes. Ecological Restoration 19:87-91.

Craft. C. B., S. W. Broome, and C. L. Campbell. 2002. Fifteen years of vegetation and soil development following brackish-water marsh creation. Restoration Ecology 10:248-258.

Craft, C. B., S. W. Broome, and E. D. Seneca. 1988. Nitrogen, phosphorus and organic carbon pools in natural and transplanted marsh soils. Estuaries 11:272-280.

Craft, C. B., and W. P. Casey. 2000. Sediment and nutrient accumulation in floodplain and depressional freshwater wetlands of Georgia, USA. Wetlands 20:323-332.

Craft, C. B., J. M. Reader, J. N. Sacco, and S. W. Broome. 1999. Twenty-five years of ecosystem development of constructed Spartina alterniflora (Loisel) marshes. Ecological Applications 9:1405-1419.

Gauch, H. G. 1982. Multivariate analysis in community ecology. Cambridge University Press, Cambridge, UK.

Gee, G. W., and J. W. Bauder. 1986. Particle-size analysis. Pages 383-411 in Methods of soil analysis, Part 1. Physical and mineralogical methods. Agronomy Monograph number 9. American Society of Agronomy-Soil Science Society of America, Madison, Wisconsin, USA.

Gibson, K. D., J. B. Zedler, and R. Langis. 1994. Limited response of cordgrass (Spartina folinsa) to soil amendments in a constructed marsh. Ecological Applications 4:757-767.

Gleason, M. L., D. A. Elmer, N. C. Pien, and J. S. Fisher. 1979. Effects of stem density on sediment retention by salt marsh cord grass, Spartina alterniflora Loisel. Estuaries 2: 271-273.

Knutson, P. H. 1988. Role of coastal wetlands in energy dissipation and shore protection. Pages 161-174 in D. D. Hook et al., editors. The ecology and management of wetlands. Volume 1 Ecology of wetlands. Timber Press, Portland, Oregon, USA. 
Kusler, J. A., and M. E. Kentula. 1989. Wetland creation and restoration: the status of the science. EPA/600/3-89/038. U.S. Environmental Protection Agency, Environmental Research Laboratory, Corvallis, Oregon, USA.

Langis, R., M. Zalejko, and J. B. Zedler. 1991. Nitrogen assessments in a constructed and a natural salt marsh of San Diego Bay. Ecological Applications 1:40-51.

Levin, L. A., D. Talley, and G. Thayer. 1996. Succession of macrobenthos in a created salt marsh. Marine Ecology Progress Series 141:67-82.

Melillo, J. M., J. D. Aber, and J. F. Muratore. 1982. Lignin and nitrogen control of hardwood leaf litter decomposition dynamics. Ecology 63:621-626.

Mitsch, W. J., X. Wu, R. W. Nairn, P. E. White, N. Wang, R. Deal, and C. E. Boucher. 1998. Creating and restoring wetlands: a whole ecosystem experiment in self-design. BioScience 48:1019-1030.

National Research Council (NRC). 1992. Restoration of aquatic ecosystems. National Academy Press, Washington, D.C., USA.

National Research Council (NRC). 2001. Compensating for wetland losses under the Clean Water Act. National Academy Press, Washington, D.C., USA.

Pickett, S. T. A. 1989. Space-for-time substitution as an alternative to long-term studies. Pages 110-135 in G. E. Likens, editor. Long-term studies in ecology. Springer-Verlag, New York, New York, USA.

Pickett, S. T. A., and V. T. Parker. 1994. Avoiding the old pitfalls: opportunities in a new discipline. Restoration Ecology $2: 75-79$.

Rheinhardt, R. D., M. C. Rheinhardt, M. M. Brinson, and K. E. Faser, Jr. 1999. Application of reference data for assessing and restoring headwater ecosystems. Restoration Ecology 7:241-251.

Ryan, M. G., J. M. Melillo, and A. Ricca. 1990. A comparison of methods for determining proximate carbon fractions of forest litter. Canadian Journal of Forest Research 20:166171 .

Sacco, J. N., E. D. Seneca, and T. Wentworth. 1994. Infaunal community development of artificially established salt marshes in North Carolina. Estuaries 17:489-500.

SAS 1996. SAS/STAT user's guide. Version 6. SAS Institute, Cary, North Carolina, USA

Scatolini, S. R., and J. B. Zedler. 1996. Epibenthic invertebrates of natural and constructed marshes of San Diego Bay. Wetlands 16:24-37.
Simenstad, C. A., and R. M. Thom. 1996. Functional equivalency trajectories of the Gog-Le-Hi-Te estuarine wetland. Ecological Applications 6:38-56.

Streever, W. J. 2000. Spartina alterniflora marshes on dredged material: a critical review of the ongoing debate over success. Wetlands Ecology and Management 8:295316.

Thayer, G. W., editor. 1992. Restoring the nation's marine environment. Maryland Sea Grant, College Park, Maryland, USA.

Updegraff, K., J. Pastor, S. D. Bridgham, and C. A. Johnston. 1995. Environmental and substrate controls over carbon and nitrogen mineralization in northern wetlands. Ecological Applications 5:151-163.

USDA Soil Conservation Service, Soil Survey Staff. 1975. Soil taxonomy. Agriculture handbook. Number 436. U.S. Government Printing Office, Washington D.C., USA.

Whigham, D. F. 1999. Ecological issues related to wetland preservation, restoration, creation and assessment. Science of the Total Environment 240:30-41.

Zedler, J. B. 1993. Canopy architecture of natural and planted cordgrass marshes: selecting habitat evaluation criteria. Ecological Applications 3:123-138.

Zedler, J. B. 1996a. Coastal mitigation in southern California: the need for a regional restoration strategy. Ecological Applications 6:84-93.

Zedler, J. B. 1996b. Tidal wetland restoration: a scientific perspective and southern California focus. Report number T-038. California Sea Grant College System, University of California, La Jolla, California, USA.

Zedler, J. B. 2000. Progress in wetland restoration ecology. Trends in Ecology and Evolution 15:402-407.

Zedler. J. B., editor. 2001. Handbook for restoring tidal wetlands. CRC Press, Boca Raton, Florida, USA

Zedler, J. B., and J. C. Callaway. 1999. Tracking wetland restoration: do mitigation sites follow desired trajectories? Restoration Ecology 7:69-73.

Zedler, J. B., J. C. Callaway, and G. Sullivan. 2001. Declining biodiversity: why species matter and how their functions might be restored in Californian tidal marshes. BioScience 51:1005-1017.

Zedler, J. B., and R. Lindig-Cisneros. 2000. Functional equivalency of restored and natural salt marshes. Pages 565-582 in M. P. Weinstein and D. A. Kreeger, editors. Concepts and controversies in tidal marsh ecology. Kluwer Academic Publishers, Dordrecht, The Netherlands. 